
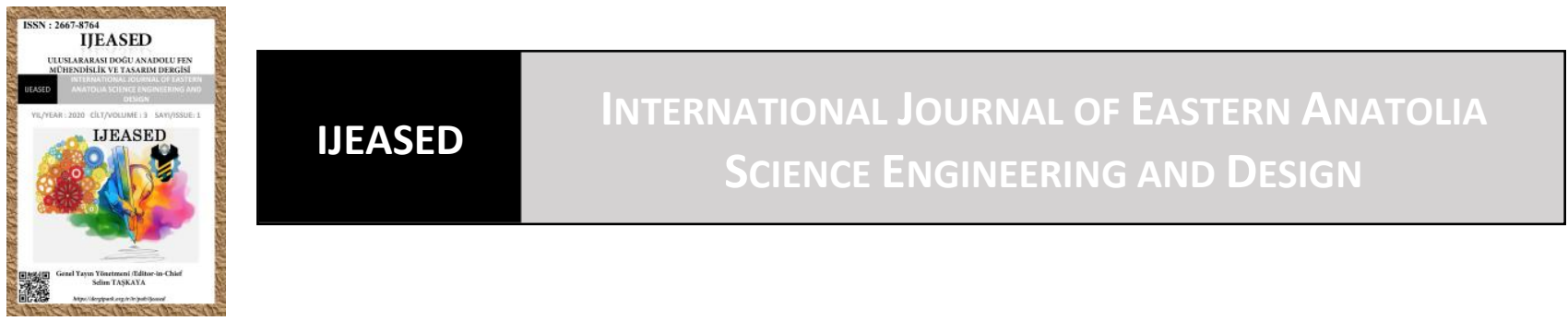

\author{
Uluslararası Doğu Anadolu Fen Mühendislik ve Tasarım Dergisi \\ ISSN: 2667-8764, 3(1), 167-191, 2021 \\ https://dergipark.org.tr/tr/pub/ijeased
}

Derleme Makalesi / Review Article

Doi: $\underline{10.47898 / \text { ijeased.849817 }}$

\title{
Fungusların Mikrobiyal Gübre veya Biyopestisit Olarak Tarımda Kullanılması
}

\author{
Meltem AVAN ${ }^{1 *}$, Recep KOTAN ${ }^{2}$
}

${ }^{1}$ Ankara Üniversitesi, Ziraat Fakültesi, Bitki Koruma Bölümü, 06110, Türkiye.

${ }^{2}$ Atatürk Üniversitesi, Ziraat Fakültesi, Bitki Koruma Bölümü, 25240, Türkiye.

\begin{tabular}{l|l|l}
\hline \multicolumn{1}{c|}{ Yazar Kimliği / Author ID (ORCID Number) } & \multicolumn{1}{|c}{ Makale Süreci / Article Process } \\
\hline "Sorumlu Yazar / Corresponding author : & Geliş Tarihi / Received Date $:$ & 29.12 .2020 \\
meltem_avn@ hotmail.com & Revizyon Tarihi / Revision Date : & 19.01 .2021 \\
\hline iD https://orcid.org/0000-0002-2939-8177, M. Avan & Kabul Tarihi / Accepted Date : & 31.01 .2021 \\
iD https://orcid.org/0000-0001-6493-8936, R. Kotan & Yayım Tarihi / Published Date : & 15.07 .2021 \\
\hline
\end{tabular}

Alıntı / Cite : Avan, M., Kotan, R. (2021). Fungusların Mikrobiyal Gübre veya Biyopestisit Olarak Tarımda Kullanılması, Uluslararası Doğu Anadolu Fen Mühendislik ve Tasarım Dergisi, 3(1), 167-191.

\section{Özet}

Funguslar, biyolojik mücadele çalışmalarında kullanılan biyolojik etmenler içerisinde önemli bir grubu oluşturmaktadır. $\mathrm{Bu}$ derlemede; biyolojik mücadelede kullanılan entomopatojenik fungusların zararlı böcek popülasyonlarının doğal dengesinin sağlanmasında ve mikorizal fungusların, bitki, toprak ve bitki patojenleri ile arasındaki etkileşimlerinin biyolojik mücadeledeki önemlerinden bahsedilmiştir. Ayrıca entomopatojenik fungusların ve mikorizal fungusların biyolojik mücadeledeki etki mekanizmaları ve bitki gelişimine katkıları hakkında bilgiler verilmiştir. Entomopatojen fungusların ve mikorizaların tarımda kimyasallara karşı gerek bitki koruma gerekse de bitki beslemede başarılı bir şekilde kullanılabileceğinin özellikle vurgulanması amaçlanmıştır. Bu konuda Türkiye'de yapılan çalışmaların biraz daha ileriye götürülmesi noktasında taşıyıcı formülasyon çalışmalarına ağırlık verilmesi ve ruhsatlandırma ile ilgili yönetmeliklerin bilimsel çalışmalara göre güncellenmesi çok faydalı olacaktır.

Anahtar Kelimeler: Fungus, Entomopatojen, Mikoriza, Biyopestisit, Mikrobiyal gübre.

\section{Use of Fungi as Microbial Fertilizer or Biopesticide in Agriculture}

\begin{abstract}
Fungi used as one of the biological factors constitute an important group in biological control studies. In this review, the role of entomopathogenic fungi used in biological control in ensuring the natural balance of pest populations and the interactions of mycorrhizal fungi with plant, soil and plant pathogens in biological control are mentioned. In addition, information was given about the action mechanisms of entomopathogenic fungi and mycorrhizal fungi in
\end{abstract}


biological control and their contribution to plant growth. It is aimed to emphasize that entomopathogenic fungi and mycorrhizaes can be used successfully both in plant protection and in plant nutrition against chemicals in agriculture. In this regard, the work done in Turkey to be taken a little further point in giving weight to the carrier formulation and updating of the regulations on licensing according to scientific studies will be very useful.

Keywords: Fungi, Entomopathogen, Mycorrhiza, Biopesticide, Microbial fertilizer.

\section{Giriş}

Tarım; ülke nüfusunun beslenmesi, milli gelire ve istihdama katkısı, sanayi sektörüne hammadde sağlaması, sanayiye sermaye aktarması, ihracata doğrudan ve dolaylı olarak katkısı, biyolojik çeşitlilikle ekolojik dengeye katkıları nedeniyle tüm dünyada vazgeçilmez olan, gıda üretiminin güvenliği nedeniyle de ülke ekonomilerini oluşturan, temel ve stratejik bir sektör niteliğindedir (Doğan ve ark., 2015). Sürekli artan dünya nüfusuna paralel olarak gıdaya olan ihtiyaç da her geçen gün artmaktadır.

Tarımda bitkisel üretim ise gerek insan beslenmesine olan direk katkısı, gerekse de hayvansal üretime olan katkılarından dolayı oldukça önem arz etmektedir. Bitkisel üretimde birçok canlı (hastalık etmenleri, zararlı etmenler ve yabancı otlar) ve/veya cansız (çevresel faktörler, toprak faktörleri, atmosferdeki zehirli gazlar ve hatalı tarımsal uygulamalar) faktörler verim ve kalite kayıplarına sebep olmaktadır. Dünyada tarımsal üretimde meydana gelen ürün kayıplarının yaklaşık olarak \%9'unu hastalıklar, \%11'ini zararlılar ve \%15'ini ise yabancı otların oluşturduğu belirtilmektedir. Bu miktar dünya tarımsal üretim potansiyelinin 1/3'üne denk olup, bunlara \%6-12 kadar hasat sonrası kayıplar da ilave edilecek olursa, mücadele yapılmadığı takdirde toplam ürün kaybının yaklaşık \%50-70’lere çıkabileceği belirtilmektedir (Agrios, 2005). Bitkisel üretimdeki bu kayıpları minimize etmek için, dünyada olduğu gibi ülkemizde de yoğun bir kimyasal gübre ve pestisit kullanılmaktadır. Ülkemizde birim alana kullanılan pestisit miktarının Avrupa Birliği Ülkeleri'ne kıyasla oldukça az olduğu ifade edilmesine rağmen, ülkemizdeki pestisit kullanımının oldukça heterojen olduğu da unutulmamalıdır (Delen ve ark., 2005). Ege ve Akdeniz Bölgeleri tüketim toplamı, genel olarak ülke tüketiminin \%34'den fazlasını, hatta bazı yıllar \%50'sine yakınını oluşturmaktadır (Delen ve ark., 2015). Son yıllarda dünyada yapılan çalışmalardan elde edilen sonuçlar, bitkisel üretimde kullanılan kimyasal içerikli bitki besleme ve bitki koruma ürünlerinin yaygın ve hatalı kullanımlarının önemli bir küresel çevre ve sağlık sorununa dönüştüğünü göstermektedir (Anonim, 2015). Ülkemizde de yapılan benzer çalışmalara göre de aynı endişeleri yansıtan sonuçlara ulaşılmıştır (Tiryaki ve ark., 2010). Bu kimyasal gübreler ve pestisitler ne yazık ki sadece uygulandığı bölgede kalmamakta, zamanla geniş bir çevreye yayılım 
göstermektedirler. Bitkilere uygulanan tarım ilaçlarının \%70 ile \%99'unun rüzgar, yağmur ve sulama yoluyla farklı ekolojik ortamlara taşındığını ve bu ortamlardaki hedef olmayan organizmalara ulaştığı ifade edilmektedir (Tiryaki, 2016). Özetle bitkisel üretimde kimyasal pestisit ve özellikle nitratlı gübrelerin yoğun bir şekilde kullanımı sonucu; topraklar, yer altı suları ve atmosferde gittikçe artan kirlilik hem dünyada hem de Türkiye'de insan ve hayvan sağlığını, yaban hayatını ve çevreyi ciddi oranda tehdit eder bir boyuta gelmiştir (Davis ve ark., 1993; Shim ve ark., 2009; Huang ve ark., 2019). Bitkisel üretimde kullanılan kimyasal bitki besleme ve bitki koruma ürünlerinin yoğun ve bilinçsiz bir şekilde kullanımı yüzünden, günümüzde toprak kirliliğinin de küresel bir sorun haline geldiği ve bu durumun sürdürülebilir tarım ve gıda güvenliği açısından büyük tehditler oluşturduğu gözlenmektedir (Kafaei ve ark., 2019).

Dünya'da pestisit kullanımında en yüksek payı \%47'lik bir oranla herbisitler almaktadır (Dağ, 2000). Bunu \%28 ile insektisitler, \%20 ile fungusitler ve \%5 ile de diğer ürünler takip etmektedir. Ülkemizde ise bitki koruma ürünleri içerisinde insektisitler \%34.72, fungusitler \%25.29, herbisitler $\% 20.28$, akarisitler $\% 6.17$, bitki gelişim düzenleyiciler $\% 3.03$, fumigantlar ve nematositler $\% 2.47$, tuzak ve feromonlar \%1.25, kış mücadele ilaçları ve yazlık yağlar \%0.93, rodentisitler ve mollusisitler \%0.73, biyolojik mücadele etmenler \%0.58 ve biyopreparatlar \%4.04'lük bir paya sahiptirler (TUİK, 2019). Burada sağlık ve çevre açısından en düşük risk içeren ürünlerin toplam kullanımdaki oranlarının en düşük seviyelerde olması oldukça dikkat çekicidir. Pestisit kullanımının bölgelere göre dağılımı incelendiğinde ise; en fazla Akdeniz Bölgesi'nde (\%30) olduğu görülmekte, bu bölgeyi sırasıyla Marmara Bölgesi (\%19), Ege Bölgesi (\%18), İç Anadolu Bölgesi (\%17), Güney Doğu Anadolu Bölgesi (\%12), Karadeniz Bölgesi (\%3) ve Doğu Anadolu Bölgesi (\%1) takip etmektedir (Anonim, 2015; Ayyıldız ve ark., 2018).

Uzun yıllardır bitkilerdeki hastalık ve zararlılardan kaynaklanan kayıpların önüne geçilmesi ve beslenme sorununun çözülmesi için en önemli çözüm yolu olarak, kimyasal tarım ilaçları ve kimyasal gübrelerin kullanılmaması olarak düşünülse de; gelinen noktada bu yaklaşımın özellikle de sürdürülebilir tarım açısından doğru olmadığı aşikârdır. Dünyada 1940’ların başına kadar zararlılar tarafindan üründe meydana gelen ortalama kayıp \%7 iken, 1980’lerin sonuna doğru bu oran \%13'e yükselmiştir (Uygun, 2002). Bu ürün kaybındaki iki katlık artış, ilaç devriminden sonra başlamış ve aynı dönem içinde ilaç kullanımında ise 12 katlık bir artış meydana gelmiştir. İlaç kullanımındaki 12 katlık artışa rağmen, ürün kayıplarındaki bu artış; ilaçlara dayanıklılığın artması, doğal düşmanların öldürülmesi, potansiyel zararlıların ekonomik zararlı durumuna geçmesi nedeniyle olduğu bildirilmiştir. Bunlara insan ve hayvan sağlığının tehdit edilmesi, gıda 
maddelerindeki ilaç kalıntıları, çevre kirlenmesi, yüksek ilaç fiyatları, ekonomik kayıp vb. yan etkiler de eklenince tarımda kimyasal bitki besleme ve bitki koruma ürünlerine alternatif çevre dostu ve daha ucuz yöntemlere ihtiyaç olduğu kaçınılamaz hale gelmiştir. Endüstriyel tarımın son 70-80 yıldır birim alandan elde edilen ürün miktarında bir miktar artışa sebep olduğu ancak bitkisel üretimde girdiler açısından üreticilere abartıldığı kadar bir katkı sağlamadığı da gözlenmektedir.

Bu yüzden; tarımda çok yoğun olarak kullanılan kimyasallara alternatif yeni yöntemlerin mutlaka geliştirilmesi gerektiği ve bunun sürdürülebilir bir tarım için zorunlu olduğu kabul edilmektedir. Özellikle de gelişmiş ülkelerde son yıllarda tarım sistemleri açısından alternatif yöntemler üzerinde durulmakta ve farklı tarım sistemlerine geçişlerin hızla yaygınlaştığı gözlenmektedir. Bu alternatif tarım sistemleri içerisinde; entegre mücadele, sürdürülebilir tarım, iyi tarım, organik veya ekolojik tarım, ekim nöbeti, solucan gübresi, yeşil gübre, hayvan gübresi, kompost, organik gübreler, bitkisel ekstre ve uçucu yağlar ve özellikle de mikrobiyal gübreler ve biyolojik kontrolden sıkça bahsedilmektedir. $\mathrm{Bu}$ alternatif mücadele yöntemleri içerisinde en çok üzerinde durulanı biyolojik yöntemlerdir. Tarımda kimyasal gübre ve pestisitlere alternatif olarak faydalı mikroorganizmaların kullanımı sürdürülebilir tarım açısından oldukça önemlidir. Bu faydalı mikroorganizmaların mikrobiyal gübre ve biyopestisit olarak tarımda kullanımına yönelik dünyada çok sayıda ticari ürün bulunmaktadır. Dünyada tescillendirilerek tarımda kullanılmak üzere piyasaya sunulan bu mikrobiyal ürünlerin büyük bir kısmı bakteri veya fungus içeriklidir ve bu ürünlerin bazıları Türkiye'de de son yıllarda başarılı bir şekilde kullanılmaktadır. Mikrobiyal gübreler ve biyopestisitlerin dezavantajı olarak raf ömürlerinin çok uzun olmaması ve çevresel koşullara da bağlı olarak etkinliklerinin gözlemlenmesinin biraz zaman alması ifade edilmiştir. Avantajları olarak da, Dünya Sağlık Örgütünün Mikroorganizma Risk Gruplandırması Listesinde riski olmayan grupta olan mikroorganizmalar kullanıldığı için insan sağlığı açısından hiç bir risk içermediği veya kimyasallara nazaran risklerinin çok daha düşük olduğu; yine kimyasallara göre daha çevreci ve doğal dengeyi koruyucu olduklarından gerek yaban hayatı gerekse de doğadaki faydalı türleri koruma açısından çok avantajlı oluşları; biyopestisitlerin sadece hedef zararlıların yada hastalıkların kontrol edilmesini sağlaması; bitkide kalıntı problemi oluşturmadığı; bakteri içerikli ürünlerde bakteriler, hem bitki besleme hem de bitki koruma açısından önemli olan birçok mekanizmaya sahip olabileceği için bitkiye çok geniş bir fayda sağladığı; toprak patojenlerine karşı oldukça başarılı olmaları; kimyasallara göre çok daha ekonomik oluşları; toprak düzenleyici özellikleri olduğundan uzun vadede toprak yapısında ciddi düzelmelere ve topraktaki zararlı kimyasalların parçalanmasına sebep olabildikleri ve bitkilerde sistemik dayanıklılık mekanizmasını 
harekete geçirerek bitkileri ekstrem koşullara karşı da koruyabildikleri ifade edilmiştir (Kotan, 2020).

Faydalı bakteriler, funguslar ve diğer organizmalar; bu biyolojik yöntemler içerisinde dünyada üzerinde en çok çalışılan ve mikrobiyal gübre ve biyopestisit olarak dünyada en çok kullanılan biyolojik çözümlerin başında gelmektedir.

\section{Entomopatojenik Funguslar}

Entomopatojenik funguslarla ilgili ilk çalışmalar 1800'lerin başında yapılmıştır ve Fransa'daki ipekböceği endüstrisinde büyük sorunlara yol açan hastalıklarla mücadelenin yollarını bulmak için çalışmalar geliştirilmeye başlanmıştır. Agostino Bassi (1773-1856), Beauveria bassiana'nın (Botrytis bassiana Bals.-Criv. olarak), ipekböceklerinin muskardin hastalığı olarak bilinen hastalığa neden olan bulaşıcı bir ajan olduğunu ifade etmiş, bu zararlı böceklerle mücadele etmek için fungal böcek patojenlerini kullanma fikri büyük ölçüde gelişmiştir (Audoin, 1837). Sonra, Pasteur (1874) ve LeConte (1874) fungusları böceklere karşı kullanılabileceklerini ifade etmişlerdir. Rusya'da, Elie Metchnikoff (1845-1916), yeşil muscardin hastalığı üzerine çalışmalar yürütmüş ve kontrol ajanı olarak Entomopthora anisopliae Metschn. (=Metarhizium anisopliae)'yi tanımlamıştır. Bu fungus, Krassilstchik (1888) tarafından üretilmeye başlanmış ve tarlada şeker pancarı bitine karşı kullanılmıştır.

Fungal mikroorganizmalar da bakteriler gibi hem bitki beslemede hem de bitki korumada ticari formülasyon haline getirilerek tarımda yaygın bir şekilde kullanılmaktadır. Dünyada yaklaşık olarak 700 farklı türe ait fungusun birçok zararlı böceğin mücadelesinde başarılı bir şekilde kullanıldı̆̆ı belirtilmektedir (Vega ve ark., 2009). Entomopatojenik funguslar olarak da isimlendirilen bu mikroorganizmalar, eklembacaklıları enfekte etme ve öldürme yeteneğine sahip parazitik mikroorganizmalardır. Bu funguslara air sporlar gelişerek, böcek gövdesine girmek için enzimatik bozunma sağlayarak, mekanik basınç yoluyla böcek kütikulasını delerek, giriş yapmaktadır (Şekil 1). 


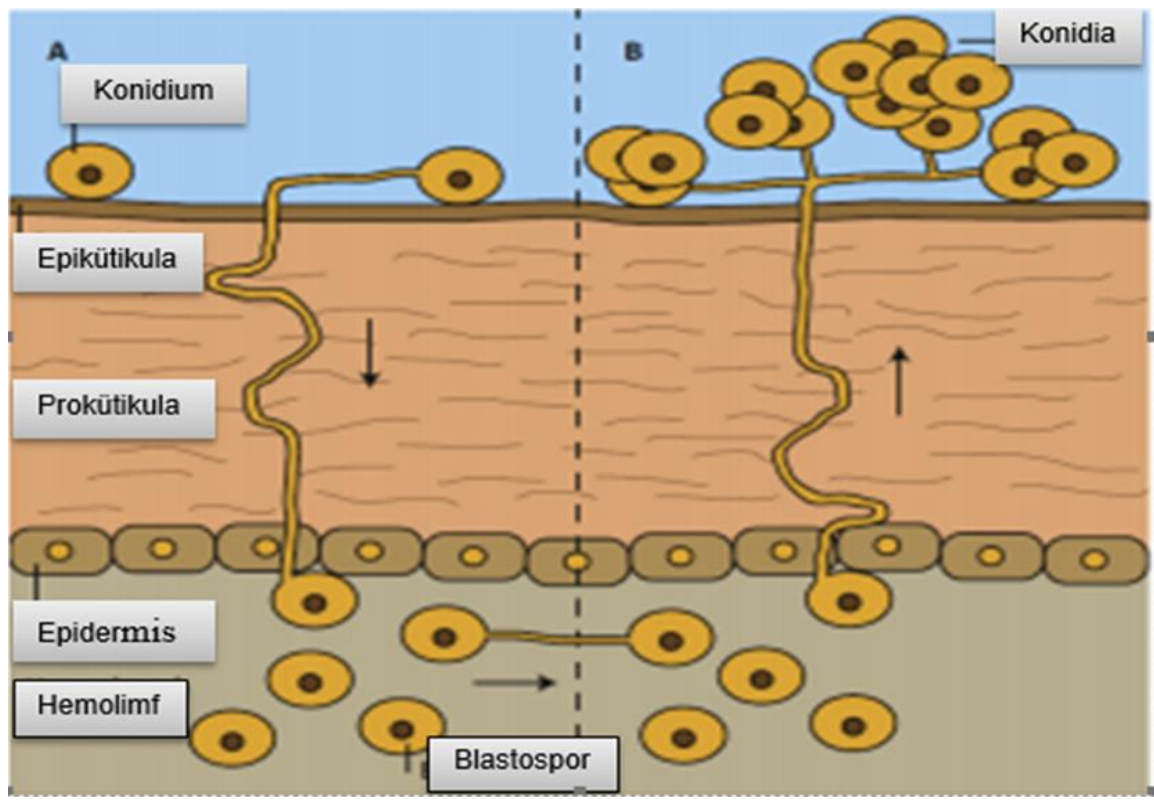

Şekil 1. Beauveria bassiana'nın gelişimi ile böcek kütikülasının enine kesiti

(Valero-Jimenez ve ark., 2016)

Böcek vücuduna girdikten sonra fungus burada çoğalarak, böcek dokularını istila edip, sporlarını üretmeye devam etmektedirler (Zheng ve ark., 2011; Xiao ve ark., 2012). Fungusun, zararlı vücudu içinde gelişen misellerinin böceğin vücut boşluğunu doldurması sonucu; zararlıyı, fiziksel olarak ve salgıladıkları toksinlerle zehirleyerek öldürmektedir (Şekil 2). Entomopatojenik fungusların özellikle uygun sıcaklıklar ve yüksek bağıl nemi olan bölgelerde ve mevsimlerde zararlı popülâsyonlarının azalmasında önemli rol oynadıkları belirtilmektedir. 


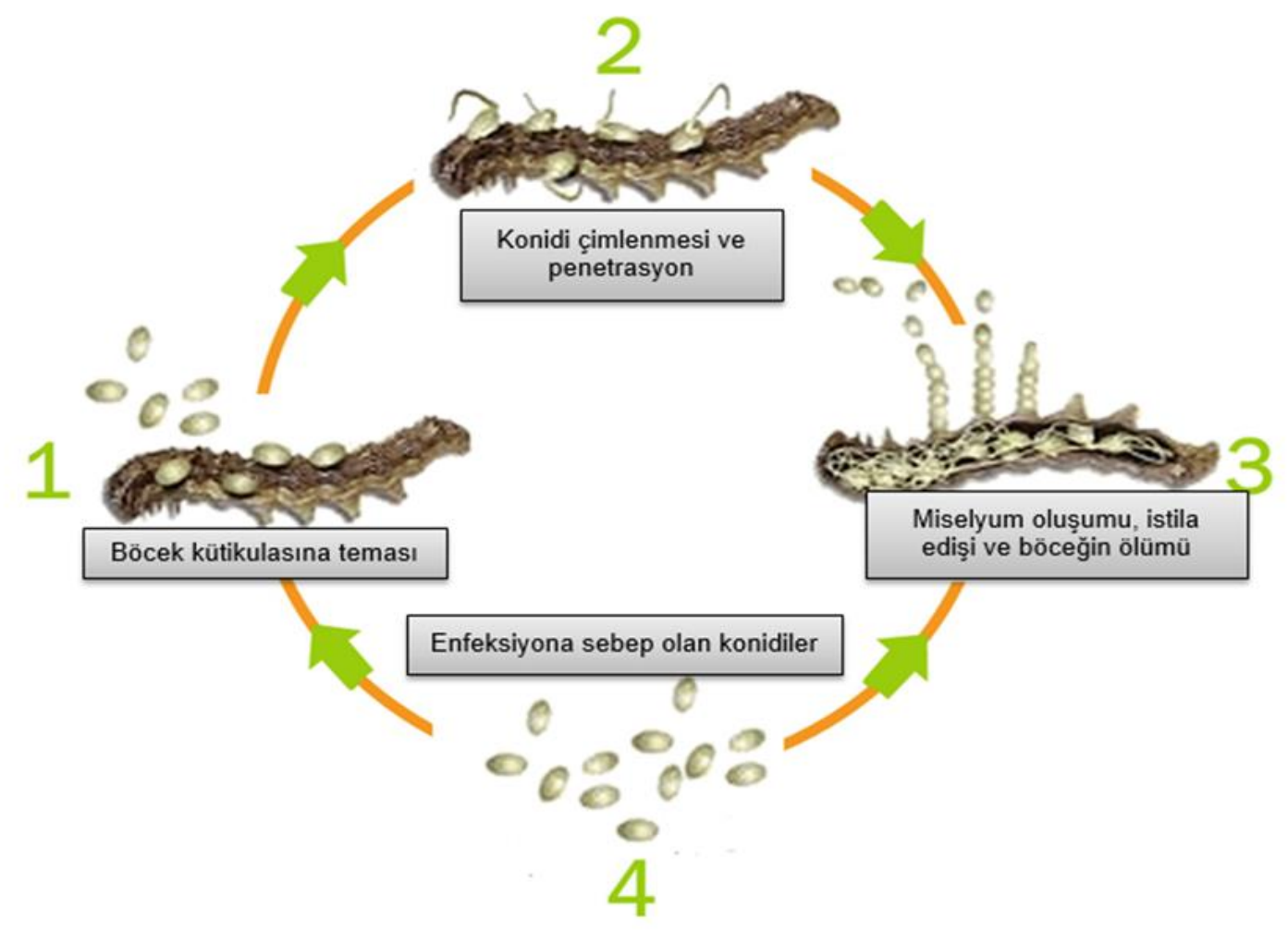

Şekil 2. Entomopatojenik funguslar tarafından enfekte olan organizmanın şematik yaşam döngüsü

(Barra-Bucarei ve ark., 2019)

Biyoajan fungusların biyokontrol mekanizmaları; besin ve yaşam yeri için patojenlerle rekabet etme, antibiyosis, mikoparazitizm, çapraz koruma ve uyarılmış sistemik dayanıklılık (ISR) olmak üzere beş sınıfa ayrılmaktadır. Bu farklı biyokontrol mekanizmaları, tek başına veya kombinasyon halinde faydalı funguslar tarafindan kullanılabilmektedir (Ghorbanpour ve ark., 2017). Biyoajan funguslar patojenlere karşı üstünlük sağlayabilmek için ürettikleri biyolojik aktiviteye sahip antibiyotik, enzim ve toksin gibi sekonder metabolitleri kullanmaktadırlar (Cantürk, 2015). Bu sekonder metabolitlerin büyük bir kısmı yararlı olan aktiviteleri içerir iken bir kısmı da istenmeyen fitotoksik ve mikotoksik gibi aktiviteleri içermektedir (Brakhage, 2013; Boruta, 2018). Entomopatojen funguslar ise ürettikleri sekonder metabolitlerinden olan bazı toksinlerin (destruksin, efrapeptinler, oosporein, beauvericin, bassianolide, beauveriolide, hirsutellin ve organik asitler) etkisi ile böceğin zayıf düşmesine, gelişimlerinin engellemesine veya ölümüne sebep olmaktadırlar (Butt ve ark., 2001).

Entomopatojen funguslar, temel olarak ekolojik tarımda biyopestisitler olarak zehirli insektisitlere oranla daha güvenli bir alternatif metod olarak kullanılmakta, bazıları da biyoteknolojik süreçlerde ve Çinde tıbbi müdahelelerde de kullanılmaktadır. Antitümör, 
Avan, M., Kotan, R., Uluslararası Doğu Anadolu Fen Mühendislik ve Tasarım Dergisi / International Journal of Eastern Anatolia Science Engineering and Design (IJEASED)

(2021) 3(1):167-191

antioksidan, immünomodülatör, antienflamatuar ve antimikrobiyal alanlar dahil olmak üzere tıbbi ve farmasötik alanlarda bu fungusların biyoaktivitelerine ilişkin kayıtlara ulaşılmıştır (Tuli ve ark. 2014). (Jaihan ve ark., 2016; Ríos-Moreno ve ark., 2016; Lovett ve Leger, 2017).

Son yıllarda fungal biyoajanların kullanılması ile bitki hastalık veya zararlılarının biyolojik mücadelesine yönelik yapılan çalışmalara göre, Metarhizium cinsine ait türler (M. anisopliae, M. robertsii, M. brunneum, M. lepidiotae, M. globosum, M. acridum, M. majus, M. flavoviride, M. rileyi, $M$ pinghaense, $M$. lepidiotae ve $M$. guizhouense), Beauveria (B. bassiana ve B. brongniartii), Isaria (I. fumosorosea - eski adı Paecilomyces fumosoroseus, I. farinosa ve I. tennuipes), Ophiocordyceps (O. sinensis (eski adiyla Cordyceps), O. unilateralis), Cordyceps (C. militaris), Torubiella (T. ratticaudata), Pochonia (P. chlamydosporia), Lecanicillium (L. lecani - eski adiyla Verticillium lecanii, L. longisporum), Hirsutella (H. thompsonii, H. nodulosa, H. aphidis) ve Paecilomyces variotii, Purpureocillium lilacinum türlerinin tarımda çok etkili bir şekilde kullanılabileceği bildirilmiştir (Khan ve ark., 2012; Tkaczuk ve ark., 2015; Jaihan ve ark., 2016).

Metarhizium, Beauveria, Paecilomyces, Isaria ve Lecanicillium cinsine ait türlere ait geniş spekturumlu birçok preparat bulunmaktadır. Bunlar çeşitli eklembacaklı türleri enfekte edebilmekte, aynı zamanda bazı hastalık etmenleri ve yabancı otlara karşı da başarıyla kullanılmaktadırlar (Khan ve ark., 2012; Castro ve ark., 2016; Ríos-Moreno ve ark., 2016).

Entomopatojenik funguslar konukçu böceğin kütikülasından doğrudan girebilmektedir ve bu nedenle özellikle Lepidoptera, Homoptera, Coleoptera ve Diptera takımlarındaki bazı zararlının mücadelesinde başarılı olabilmektedirler (Şekil 3).

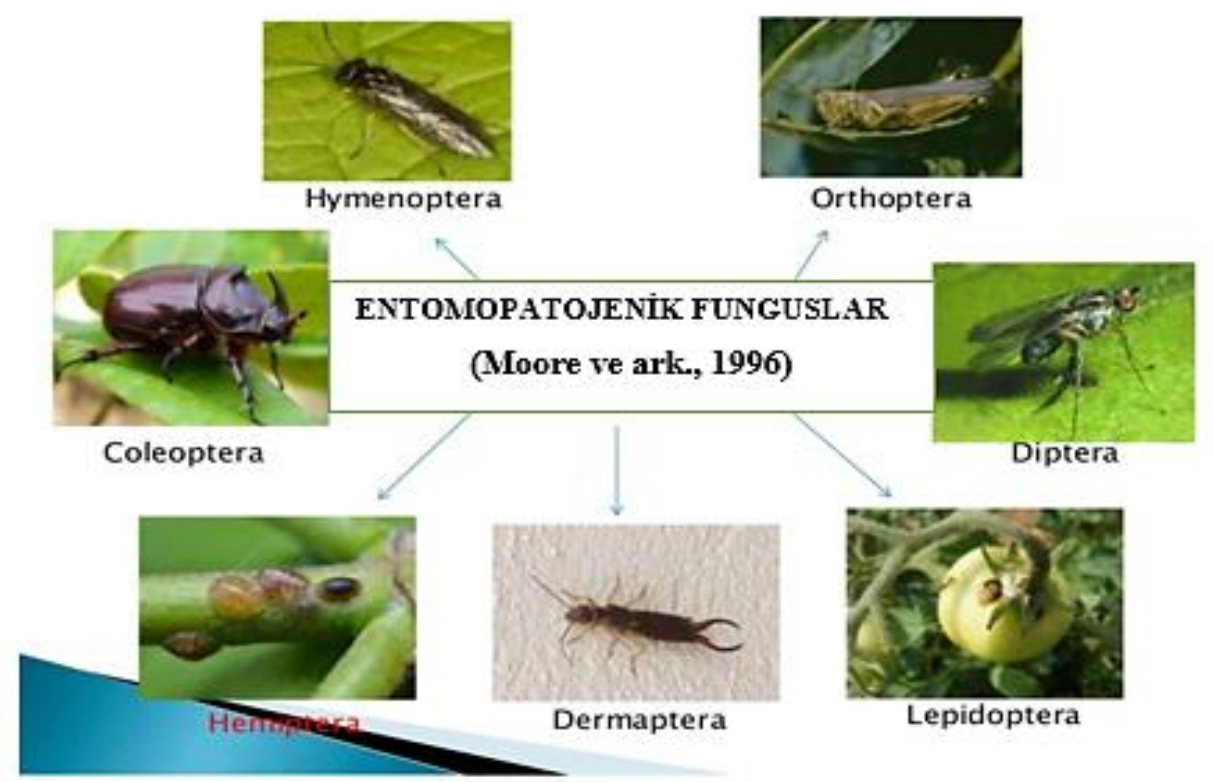

Şekil 3. Entomopatojenik fungusların yer aldığı böcek takımları (Moore ve ark., 1996) 
Bitki üzerinde bulunan ve entomopatojen funguslar ile enfekte olmuş böcekler toprağa düşerek toprakta önemli fungus rezervini oluşturmaktadırlar. Ayrıca toprak ortamı, fungusları UV 1şınlarından koruduğu, biyotik ve abiyotik etkenlere karşı tampon görevi gördüğü için fungusların uzun süre canlılığını korumasını sağlamaktadır. Tarımsal ekosistemlerde toprakta çok sık rastlanan ve dünya çapında yaygın olarak bulunan B. bassiana geniş konukçu kitlesine sahip Hypocreales (Ascomycota) takımına bağlı entomopatojenik bir fungustur. Bazı entomopatojen funguslar tarafından enfekte olmuş böcekler Şekil 4'de verilmiştir.

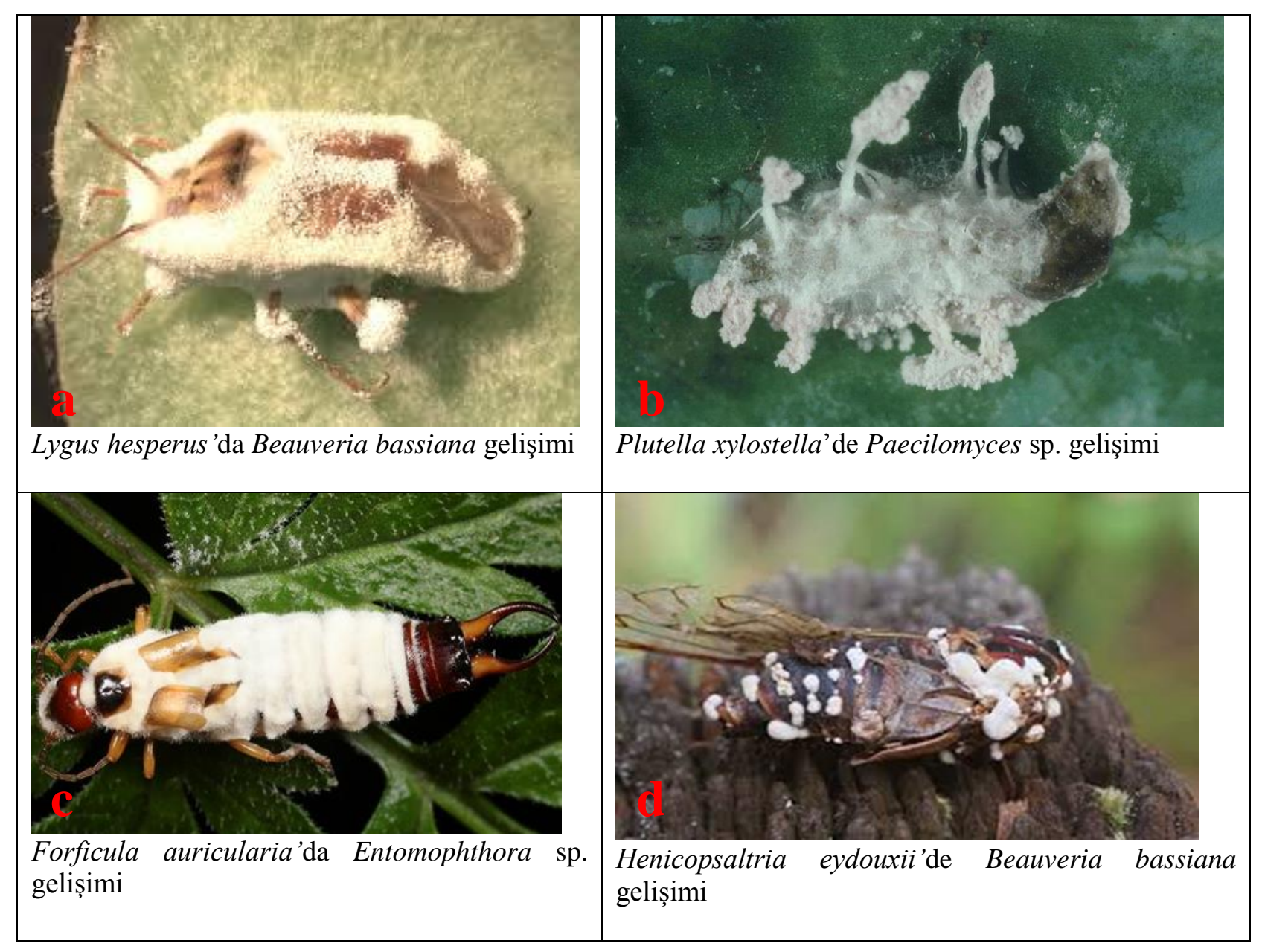




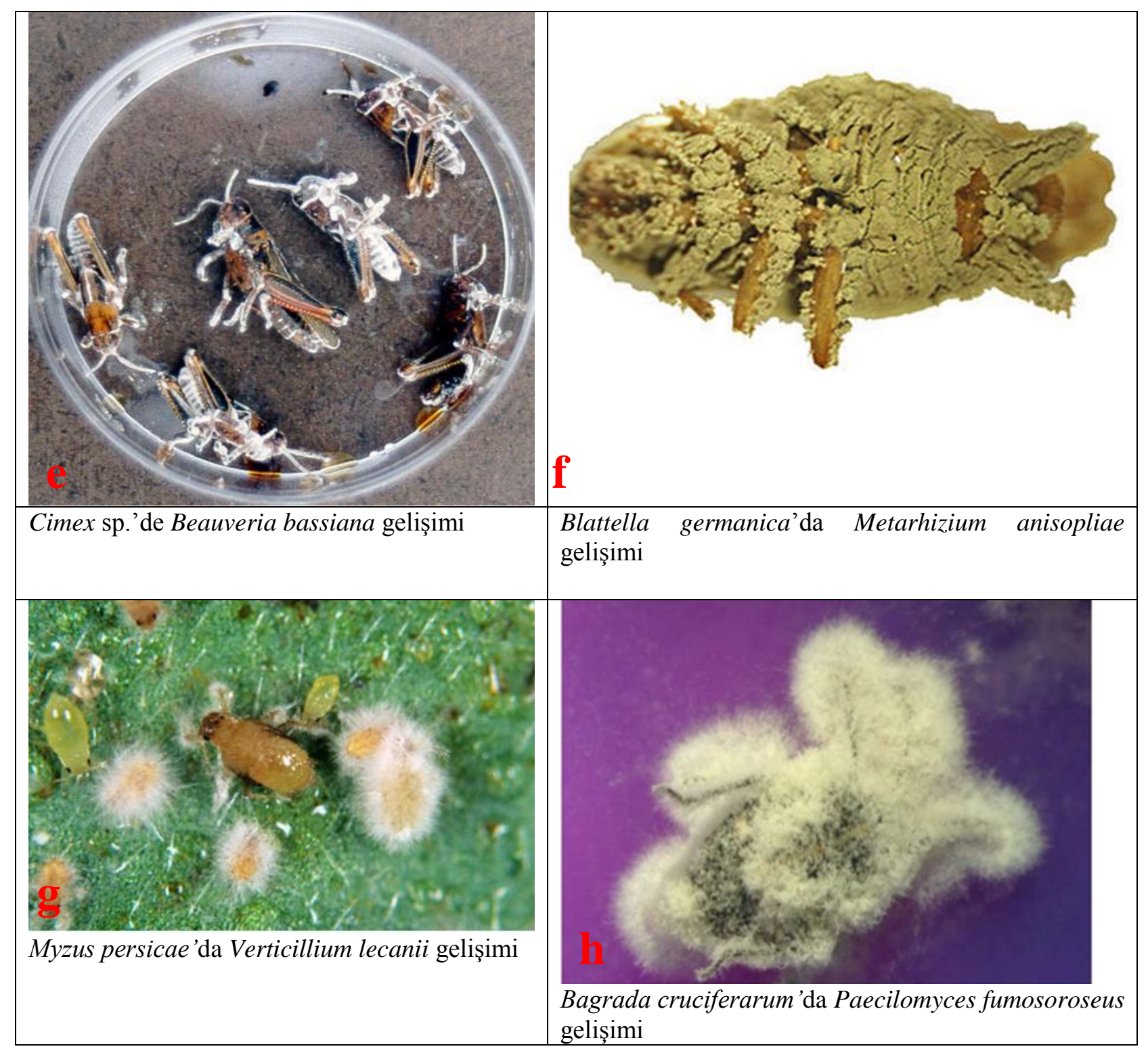

Şekil 4. Bazı entomopatojen funguslar tarafindan enfekte olmuş böcekler

(a ve h: Fotoğraf: Surendra Dara, E-Journal of Entomology and Biologicals, 2017), (b: Forestry images, 2018), (c: Labroots, 2017), (d: Jungle Dragon, 2019), (e, f: Wikipedia, 2021a; Wikipedia, 2021b), (g: Alamy, 2012)

Piyasada biopreparatı bulunan diğer bazı entomopatojenik funguslar ve etkili oldukları hastalık veya zararlı grupları Tablo 1'de verilmiştir. 
Tablo 1. Bazı entomopatojenik funguslar ve ticari ürünleri (Dara, 2017; Maina ve ark., 2018; Kotan, 2020).

\begin{tabular}{|c|c|c|}
\hline Entomopatojen Funguslar & Ticari Ürünü & Etkili Olduğu Zararlı Grupları \\
\hline Beauveria bassiana & $\begin{array}{l}\text { Bio Power } \\
\text { BotaniGard ES } \\
\text { Mycotrol-ESO } \\
\text { Myco-Jaal } \\
\text { Naturalis-L } \\
\text { Betal } \\
\text { Ostrinol }\end{array}$ & $\begin{array}{l}\text { Yeşilkurt, yaprak galeri sineği, kabuklu bit, } \\
\text { çekirge, yaprak yiyen böcekler }\end{array}$ \\
\hline $\begin{array}{l}\text { Verticillium lecani } \\
\text { (=Lecanicillium lecanii) }\end{array}$ & $\begin{array}{l}\text { Bio Catch } \\
\text { Vertalec } \\
\text { Mycotal } \\
\text { Phule Bugicide }\end{array}$ & $\begin{array}{l}\text { Beyazsinek, thrips, afit, koşnil, unlu bit gibi } \\
\text { zararlılar }\end{array}$ \\
\hline Metarhizium anisopliae & $\begin{array}{l}\text { Bio Magic } \\
\text { BioCane } \\
\text { Metarril } \\
\text { Ory-x } \\
\text { BioBlast } \\
\text { Green Muscle }\end{array}$ & $\begin{array}{l}\text { Yeşil kurt, pembe kurt, gövde kurdu, iç kurtları, } \\
\text { pamuklu bit, yaprakbükenler ve larvaları, } \\
\text { termitler, çekirgeler }\end{array}$ \\
\hline Metarhizium brunneum & Met52 EC & Beyaz sinek, thrips, akarlar, keneler \\
\hline $\begin{array}{l}\text { Isaria fumosorosea (=Paecilomyces } \\
\text { fumosoroseus) }\end{array}$ & $\begin{array}{l}\text { Priority } \\
\text { Nofly WP } \\
\text { PFR-97 WDG }\end{array}$ & $\begin{array}{l}\text { Kırmızı örümcek, Avrupa kırmızı örümcek ve } \\
\text { kahverengi akarlar }\end{array}$ \\
\hline Paecilomyces lilacinus & $\begin{array}{l}\text { Bio Nematon } \\
\text { MeloCon WG }\end{array}$ & $\begin{array}{l}\text { Kök ur nematodu, kist nematodu, sogansak } \\
\text { nematodu }\end{array}$ \\
\hline Trichoderma viride & Bio Cure F & $\begin{array}{l}\text { Kök çürüklüğü, çökerten, gövde çürüklüğüü, } \\
\text { kurşuni küf, açık rastık, yaprak lekesi }\end{array}$ \\
\hline Hirsutella thompsonii & $\begin{array}{l}\text { ABTEC Hirsutella } \\
\text { Mycohit }\end{array}$ & Coleoptera, Diptera, Hemiptera \\
\hline Lecanicillium longisporum & Vertalec & Afit \\
\hline
\end{tabular}

Zararlı kontrolünde sıklıkla entomopatojenik funguslarla (B. bassiana veya $M$. anisopliae) dönüşümlü olarak kullanılan insektisitlerden; özellikle Organofosfat (Profenophos ve Metil Demeton) ve kloroorganik insektisitler (indoxacarb), B. bassiana üzerinde çok yüksek zararlara sebebiyet vermişlerdir (Amutha ve ark., 2010). Organofosfat Lorsban ise, M. anisopliae ve I. fumosorosea'ya karşı en yüksek toksisiteyi göstermiş, fungusun miselyal gelişmesinde ve konidial çimlenmesinde yüksek oranda azalmalara neden olmuşlardır. Carbamatlardan (Lannate, Larvin) ve bir pyrrole insektisiti ise (klorfenapir; Korsan) M. anisopliae ve I. fumosorosea'ya karşı orta düzeyde toksisite meydana getirmişlerdir (Asi ve ark., 2010). Pyrethroidlere ait insektisit olan Lambda Cyhalothrin'in olumsuz etkisi bu funguslarda daha azdır (Tkaczuk ve ark., 2015). Yine Pyrethroid insektisitlerden Deltamethrin B. bassiana'nın koloni oluşturan biriminde önemli azalmalara neden olmuştur. Fakat B. bassiana Deltametrinin zararlı etkilerine yanıt olarak savunma mekanizmalarını aktive ettiğini gözlemlenmiştir (Forlani ve ark., 2014). Başka bir inseksitisit grubu 
olan Neonicotinoidlerden Acetamiprid ve Thiamethoxam uygulamalarının B. bassiana üzerinde toksik etkileri tespit edilirken, Acetamiprid uygulamaları da $M$. anisopliae gelişimi üzerinde azalmalara sebebiyet vermiştir. Fakat arılar için oldukça toksik olan ve birçok ülkede yasaklanmış olan İmidacloprid'in çok ilginç bir şekilde entomopatojen funguslar üzerinde olumsuz bir etkisi görülmemiştir (Neves ve ark., 2001).

Doğal insektisitler bu funguslar için daha az toksiktir. Saccharopolyspora spinosa'dan izole edilen Spinosad, $M$. anisopliae ve I. fumosorosea'da sadece yaklaşık \%7-8 miselyum gelişiminde azalmaya ve yaklaşık \%20 oranında ise konidiyal çimlenmede azalmaya neden olmuştur (Asi ve ark., 2010). Başka bir doğal insektisit olan neem yağının (bitkilerden türetilmiş) entomopatojenik funguslara olumsuz etkisi tespit edilmiş ve $M$. anisopliae ve $B$. bassiana'da konidi üretimini ve vejetatif büyümeyi azalttı̆̆1 gözlemlenmiştir (Hirose ve ark., 2001).

İnsektisitlerin entomopatojenik funguslar üzerindeki etkileri üzerine çalışmalar halen devam etmektedir. Bu çalışmaların genel amacı, zararlı kontrolünde entomopatojenik funguslarla birlikte daha düşük dozlarda insektisit kullanımını yaygınlaştırmaktır. Bu şekilde daha düşük insektisit doz kullanımıyla, entomopatojenik funguslarla beraber kullanımı, toksik bileşiklerin oluşumu ve küresel çevre kirliliğinin azalmasına yardımcı olacaktır (Subbanna ve ark., 2019).

Quizalofop-p-ethyl ve Glyphosate etken maddeli herbisitler H. nodulosa ve B. bassiana gelişiminde azalmalara neden olmuşlardır (Tkaczuk ve ark., 2015). S-triazine herbisit olan Ametryn bu funguslarda büyümeyi azaltmış, glikozun M. brunneum tarafından bozulmasını yavaşlatmış, karbon ve azot metabolizmasını da bozmuş, misellerde oksidatif strese neden olmuştur (Szewczyk ve ark., 2018).

Fungisit kullanımında da durum insektisitlerinkine benzemektedir. I. fumosorosea, daha yüksek oranda eşdeğer metalik bakır içeren bakır bazlı fungisitlere duyarlıdır (Avery ve ark., 2013). Düşük bakır dozları içeren fungisitlerin I. fumosorosea ve I. farinosa'nın gelişimi üzerine bariz bir etkisi olmamışken (D'Alessandro ve ark., 2011; Demirci ve ark., 2011; Avery ve ark., 2013 ), bakır oksidin toksik etkisi B. bassiana ve L. muscarium için doğrulanmıştır (Kouassi ve ark., 2003; Ali ve ark., 2013). Moleküllerinde metal (Zn, Mn) bulunduran dithiocarbamate fungisitler B. bassiana ve I. farinosa üzerinde engelleyici etkisi tespit edilmiştir (Todorova ve ark., 1998; Kouassi ve ark., 2003). Düşük dozlarda uygulanan mancozeb ve propineb, B. bassiana'nın sporülasyonunu engellemektedir (Celar ve Kos, 2016). Chlorothalonil B. bassiana gelişiminde çok az olumsuz bir etki sağlarken, bu fungisitin düşük konsantrasylarının I. farinosa ve B. bassiana'nın konidiyal çimlenmesini ciddi şekilde engellediği tespit edilmiştir (Demirci ve ark., 2011; Celar ve Kos, 2016). 
Chlorothalonil aynı zamanda sporulasyon ve gelişmede azalmaya neden olarak B. bassiana ve $M$. anisopliae'ye fungisit etkisi göstermiştir (Fiedler ve Sosnowska, 2017). Bu fungisit aynı zamanda $L$. muscarium sporlarının çimlenmesini engellemiştir (Bagga ve ark., 2004). Captan etken maddeli fungisit, miselyal büyümeyi az miktarda engellerken, B. bassiana, I. fumosorosea, L. longisporum konidiyal çimlenmesini daha fazla miktarda engellemiştir (Shah ve ark., 2009; Dara 2017). Triazole fungisitlerden Tebuconazole entomopatojenik funguslara zararlı etkisi daha çoktur ve $B$. bassiana, M. anisopliae ve L. lecanii gelişimlerini büyük oranda engellemiştir. Difenaconazole, Tricyclazole ve Myclobutanil ise L. lecanii ve L. muscarium için toksik olarak bulunmuştur (Demirci ve ark., 2011; Reddy ve ark., 2018). Tebuconazole ise P. lilacinus 'de oldukça toksik bulunmuştur (Demirci ve ark., 2011). Strobilurin fungisidi olan Azoxystrobin, B. bassiana ve M. anisopliae'nin gelişimine ve sporulasyonunda, I. fumosorosea'nın ise konidiyal çoğalmasında oldukça olumsuz etkili olduğu tespit edilmiştir (D'Alessandro ve ark., 2011; Fiedler ve Sosnowska, 2017). Ayrıca M. majus'a karş1 orta derecede toksisite oluşmasına da neden olmuştur (Sivakumar ve ark., 2019). Son çalışmalara göre, entomopatojenik fungusların fungisitlere karş1 hassasiyetinin, sadece sporlar yerine mikroskleroti kullanılarak daha da azaltılabileceğini düşündürmektedir (Wu ve ark., 2020).

Endüstriyel boyalar da entomopatojenik fungusların gelişimini olumsuz açıdan etkileyebilmektedir (Gola ve ark., 2018).

Entomopatojenik funguslar ayrıca toksik maddeleri, bünyelerinde bulunan enzimler sayesinde ortamdan uzaklaştırmak için de kullanılabilmektedir. Örneğin, M. robertsii ve M. brunneum türleri nonilfenolleri, triazinleri, kalay bileşiklerini, sentetik östrojeni, hidrokarbonları ve endüstriyel boyaları parçalayabilme özelliğine sahiptirler. Ayrıca bu fungusların morfolojilerini ve hif gelişimini olumsuz etkileyen ağır metallarle etkileşime girerek bunların ortamdan uzaklaşmasını sağlamaktadırlar (Litwin ve ark., 2020).

Entomopatojenik fungus kullanımının zararlı yönetiminde başarılı olup olmadığını tespit ederken öncelikle her bir vakayı ayrı ayrı düşünmek gerekmektedir. İnseksitlerle doğrudan karşılaştırmalar yapmak genellikle uygun olmamaktadır. Gelernter ve Lomer (2000), herhangi bir mikrobiyal kontrol ajanının başarılı olması için öncelikle teknik yeterlilik gerekli olduğunu ve pratik etkinlik (kolay ve ucuz alım), ticari uygulanabilirlik (kârlılık), sürdürülebilirlik (uzun vadeli kontrol) ve/veya kamu yararı (güvenlik) gibi faktörlerin de önemli olduğunu bildirmişlerdir.

Yapılan çalışmalara göre entomopatojenik fungusların, insanlara, çevreye ve hedef olmayan organizmalara karşı olumsuz etkilerinin minimal düzeyde olduğu ve entegre mücadelede 
kullanımının insektisitlere göre çok daha güvenilir bir alternatif olduğu tespit edilmiştir (Goettel ve Hajek, 2000; Pell ve ark., 2001; Tozlu ve ark., 2017; Tozlu ve ark., 2018a,b).

\section{Mikorizalar}

Tarımda fungusların yaygın bir şekilde kullanıldığı bir diğer alan da mikorizalardır. Mikoriza, Yunanca mykes (mantar) ve rhiza (kök) kelimelerinin bir araya gelmesi ile oluşan "Kök mantarı" anlamına gelen bir terimdir. İlk kez A.B. Frank tarafından 1885 yılında mantar-ağaç ilişkisini tanımlamak için kullanmıştır. Fungus ve kökler arasındaki mikorizal ilişkisi, dünyadaki bitkilerin yaklaşık \%92'sinde görülmektedir (Isaac, 1992). Mikoriza ekolojik olarak doğal dengenin korunmasını sağladığı için besin döngüsü ve bitkinin hayatta kalması için büyül bir öneme sahiptir (Harley ve Smith, 1983). Bu ilişki ile bitki, mikorizal fungusa karbon; mikorizal fungus da bitkiye su ve besin elementi temin etmektedir (Smith ve Read, 1996).

Tüm dünyada olduğu gibi Türkiye'de de hızlı nüfus artışı sebebiyle insanların ihtiyacı da artmakta bununla beraberde insanlar artan bu ihtiyaçları tedarik etmek için daha fazla ürün yetiştirmeye çalışmaktadır. Bunun sonucunda da kullanılan aşırı sentetik gübre ile toprak ve su kirlenirken, fazla kompoze gübre kullanımı ile de ekolojik denge bozularak, ekosisteme zarar vermektedir. $\mathrm{Bu}$ nedenle yetiştirme alanlarının ıslah edilme çalışmalarında toprak ve suyu kirletmeden ve ekolojik dengeyi bozmadan çalışmak gerekmektedir. $\mathrm{Bu}$ da mikoriza gibi doğal yöntemlerden yönelimi sağlamaktadır.

Yapılarına ve işlevlerine göre dört çeşit mikoriza bildirilmiştir. Bunlar arbusküler mikoriza (AM) (endomikoriza), ektomikoriza (EM), orkide mikoriza ve erikoid mikorizalardır (Şekil 5) (van der Heijden ve ark., 2015). Mikorizal funguslar, bitki köklerinin korteksinde, kök yüzeyinde veya kökün epidermal hücrelerinin etrafında yaşamaktadırlar. Bu funguslara ait hifler ayrıca köklerden toprağa doğru gelişir ve burada bitki büyümesini sınırlayan besinler, özellikle nitratlar ve fosfatlar, ancak organik olarak bağlı besinler de bazı mikorizal türler tarafından alınır (Read ve PerezMoreno, 2003). Bu besinler ve diğer maddeler daha sonra karbonhidratlar almak suretiyle konukçu bitkilere verilir (Smith ve Read, 2008). Sonuç olarak, mikorizal simbiyoz etkisi ile bitkinin gelişim tamamlanmaktadır. Farklı mikorizal türlerle ilişkilendirilen ve üç farklı toprakaltı ağı oluşturan bitki türlerinin oluşturduğu varsayımsal bitki topluluğunun çizimi Şekil 6'da sunulmuştur.

Endomikorizalar daha çok Glomeromycota, ektomikorizalar ise Basidomycota üyesi funguslarca oluşturulurlar. Günümüzde çok sayıda bitkinin funguslarla simbyotik bir ortaklık oluşturduğu tespit edilmiştir. Mikorizal fungusların, farklı bitki türleri ile etkileşime girerek 
bitkilerin yararına gösterdikleri etkileri arasında, bitkilerde direnç sistemini geliştirerek olumsuz çevre koşullarına karşı korumak, bitkinin topraktan alamadığı bitki besin elementlerinin alınımını sağlamak ve bitkinin çeştli bitki hastalıklarına karşı direncini arttırmak bulunmaktadır. En yaygın kullanılan mikorizal türler; Glomus fasciculatum, Glomus mosseae, Glomus intraradices, Glomus etunicatum, Glomus versiforme, Glomus margarita, Glomus coledonium ve Trichoderma harzianum'dur.
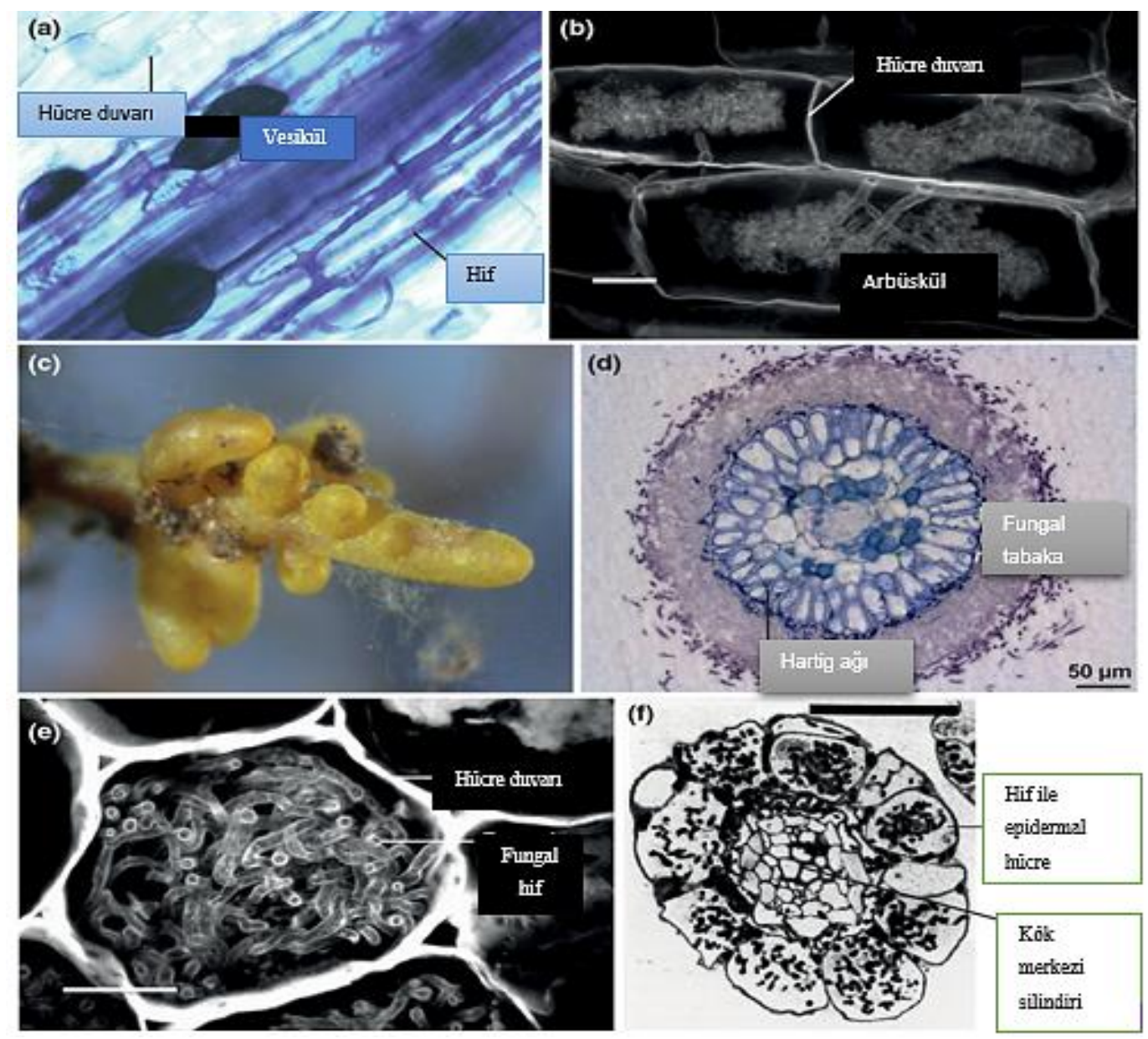

Şekil 5. Arbüsküler mikorizanın tipik yapısı (a, b); ektomikorizalar (c, d); orkide mikorizalar (e); erikoid mikorizalar tipik yapıları (f)

(a) van der Heijden ve ark., 2015; (b) Ryan Geil, yayınlayan Peterson ve ark. (2004); (c) Marc Buée, INRA; (d) Maira de Freitas Pereira, INRA; (e) Carla Zelmer , yayınlayan Peterson ve ark. (2004); (f) Paola Bonfante 


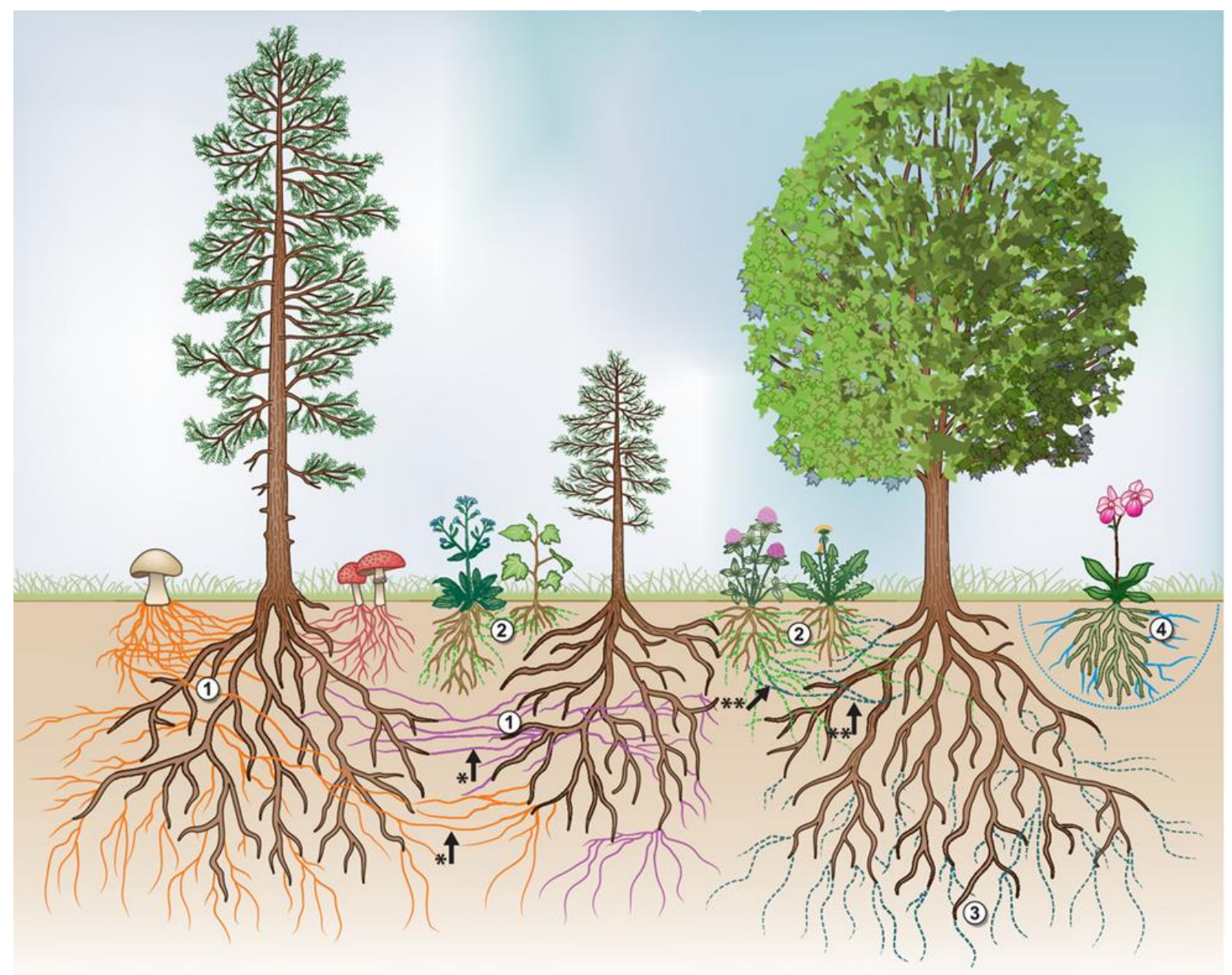

Şekil 6. Farklı mikorizal türlerle ilişkilendirilen ve üç farklı toprakaltı ağı oluşturan bitki türlerinin oluşturduğu varsayımsal bitki topluluğunun çizimi (van der Heijden ve ark., 2015).

En geniş gruba sahip olan endomikorizaların en bilineni Vasiküler Arbusküler Mikoriza (VAM)'dır (Ortaş, 1997). Kök korteksi içerisinde kolonize olan VAM çok miktarda misel üreterek bitki kök yüzey alanını arttırmakla beraber bitkinin kökünden oldukça uzakta bulunan ve bitkinin topraktan alamayacağı formdaki ve miktardaki fosfor, azot, potasyum, demir, çinko, bakır ve molibden gibi besin maddelerini miselleri yoluyla almakta ve bu sayede bu maddelerin bitkinin üst aksamına taşınmasına yardımcı olmaktadırlar. Bunun dışında bünyelerindeki su tutabilme yeteneği sayesinde bitkinin su stresine girmesine mani olurlar. Bitki de mikorizal fungusa karbon sağlayarak simbiyotik bir hayat döngüsü gerçekleştirmektedirler (Şekil 6) (Marschner ve Dell, 1994; Ortaş, 1997; Al-Karaki, 2000).

Mikorizalar, oluşturdukları misel yapıları ile bitkilerin kök sistemlerine yerleşerek bitki köklerinden salgılanan bazı maddeler ile beslenirken bitkinin de topraktan daha iyi yararlanmasını sağlamaktadırlar. Bu ilişside mikorizal fungus, gelişimi için bitkiden karbon ve esansiyel organik 
maddeler temin ederken; bitkinin de su ile besin elementleri, tuz ve metabolitleri almasına yardımcı olmaktadır. Böylece, bu etkileşimde her iki taraf da yarar sağlamaktadır (Şekil 7).

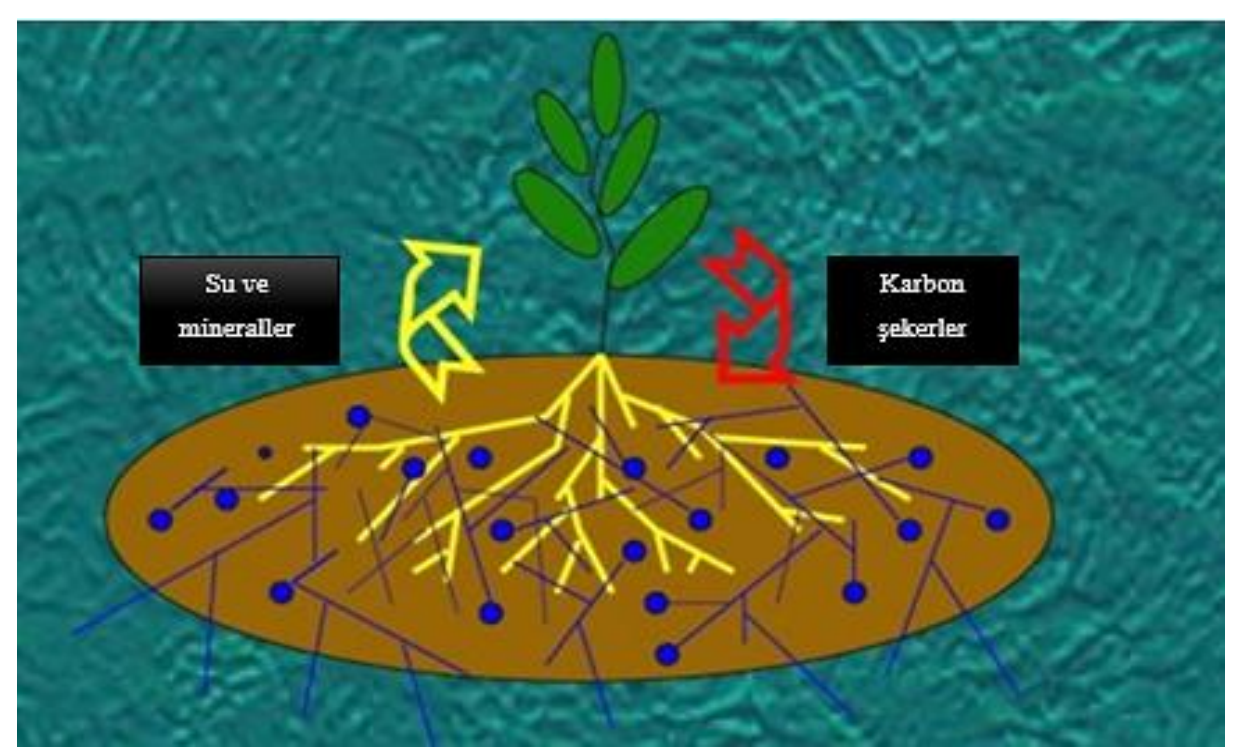

Şekil 7. Bitki ve funguslar arasındaki besinlerin çift yönlü değişimi (Government of Canada, 2013)

Mikorizal funguslar, bir arada olan bitkiler arasında kaynakların taşınmasına müsaade eden bir hifsel ağ yoluyla bitkileri toprak altına bağlamaktadırlar (Şekil 8).

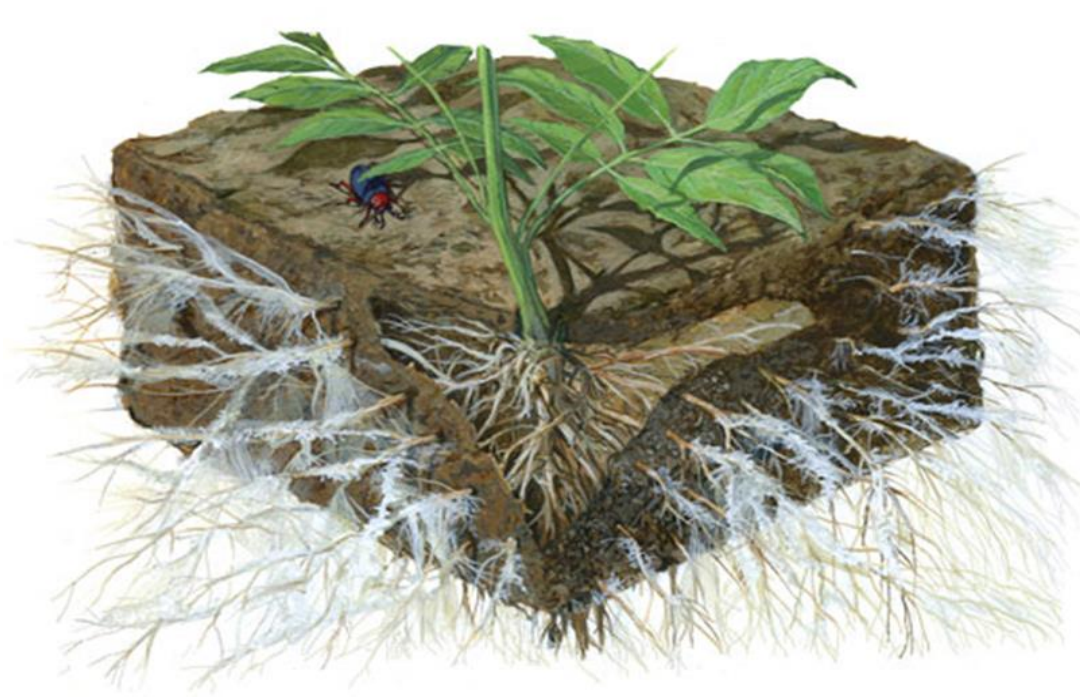

Şekil 8. Mikorizaların bitkilerin kök sistemlerine yerleşerek oluşturdukları misel yapıları (Çizim Michael Rothman) (The Ground up, 2018) 
Arbüsküler Mikorizal Funguslar da (AMF), bitki hastalıklarına karşı önemli bir biyokontrol ajanı olarak kullanılmaktadır (Tahat ve ark., 2010). Bu funguslar, bitki kök sistemi gelişimi ve rizosfer kolonizasyonu için oldukça önemlidirler ve bu özellikleri sayesinde patojenlerine karş1 üstün rakipler haline gelmişlerdir (Vos ve ark., 2014). Ayrıca, AMF’ler, bitkiyi patojenden korumak için konukçularında fizyolojik ve anatomik değişiklikler yaparak, kök lignifikasyonunun arttırarak, konukçu hücre duvarının pektin ile kalınlaştırılması gibi mekanizmaları sağlayarak dolaylı olarak da patojeni engelleyebilmektedirler (Malik ve ark., 2016). AMF'lar bitki savunma sistemini etkileyerek bitki-patojen etkileşimlerini de değiştirebilmektedirler. Örneğin, bir AM fungus olan Glomus fasciculatum'un lipoksigenazlar (LOX) ve fenilalanin amonyum liyazı (PAL) kodlayan jasmonik asit (JA) yolu savunma genlerinin ekspresyonunda üç kat artışa sebep olurken, fungal patojen olan Alternaria alternata'ya karşı da domateste sistemik direnci artırdığı tespit edilmiştir (Nair ve ark., 2014). Bir endofit fungus olan Piriformospora indica'nın hidrojen peroksit birikimi ve süperoksit dismutaz ve guaiacol peroksidazın uyarılmasını sağlayarak çeltik kılıf yanıklığına (sheath blight) karşı ISR'yi artırdığı gözlemlenmiştir (Nassimi ve Taheri, 2017). Ektomikorizal funguslardan, Alnicola sp., Laccaria fraterna, Lycoperdon perlatum, Pisolithus albus, Russula parazurea, Scleroderma citrinum, Suillus brevipes ve Suillus subluteus olmak üzere sekiz adet ektomikorizal fungusun; Alternaria solani, Botrytis sp., Fusarium oxysporum, Lasiodiplodia theobromae, Phytophthora sp., Pythium sp., Rhizoctonia solani, Sclerotium rolfsii ve Subramaniospora vesiculosa da dahil olmak üzere birçok fungal patojene karş1 antagonistik etki gösterdiği gösterdiği bildirilmiştir (Mohan ve ark., 2015). Arbüsküler mikorizal funguslar (AMF); konukçu bitkilerini birçok önemli üründe büyük zarar yapan bitki-paraziti nematod enfeksiyonlarına karşı da bitki toleransını artırarak, besinler ve yaşam alanı için doğrudan rekabet ederek, uyarılmış sistemik dayanıklılık (ISR) mekanizmasını uyararak ve rizosferdeki etkileşimleri bir koruyuculuk sağladıkları bildirilmektedir (Schouteden ve ark., 2015).

Mikorizaların; bitkideki su ve besin maddesi alınımını artırdığı, bitki gelişimini artırdığı, antioksidant enzimlerinin çoğalarak abiyotik ve biyotik faktörlere karşı dayanıklılığını artırdığ 1 bildirilmiştir (Pfeiffer ve Bloss, 1988; Ruiz- Lozano, 2003). Su ve besin maddesi alınımını arttırdığ1 için de kimyasal gübrelere olan ihtiyaç da zamanla azalmıştır (Millner, 1991; Ortaş, 1997). Ayrıca mikorizal enfeksiyon, kirletilmiş toprakların bitki bünyesi üzerindeki olumsuz etkilerini azaltabilmektedir. Mikoriza, bitkiyi hem hastalık ve zararlara karşı hem iyi besin almasını hem korunmasını hem de rizosferde diğer organizmalarla mücadele ederek daha etkin duruma gelmesini sağlamaktadır (Dehne ve Schanbeck, 1979). 
Son y1llarda arbüsküler mikoriza funguslarının büyük ölçekli üretimi için yeni yöntemler geliştirilmiş olmakla birlikte (Ijdo ve ark., 2011) bu tarz funguslarla tohum kaplama teknolojisi ivme kazanmıştır (Vosátka ve ark., 2012). Birçok çalışmada laboratuvar koşullarında üretilen arbüsküler mikoriza funguslarının bitkilerde önemli verim artışları sağlandığı görülmüştür. Ceballos ve ark. (2013), bitki köklerine uygulanan arbüsküler mikorizalardan Rhizophagus irregularis'in manyok bitkisinde (Manihot esculenta Crantz), inorganik fosfat alımını artırdığı, bitki gelişim parametrelerinde ve verimde önemli artışlara sebep olduğunu belirtmiştirlerdir.

\section{Sonuçlar ve Öneriler}

Son yıllarda çok daha iyi anlaşılmıştır ki, tarım, dünya için olduğu kadar ülkemiz için de asla ihmal edilmemesi gereken stratejik bir sektördür. Bitkisel üretimde bir asra yakın süredir devam eden yoğun kimyasal kullanımının, sağlık ve çevre üzerine verdiği zararının artık çok büyük boyutlara geldiği aşikârdır. Bu kimyasallar ile sağlık, çevre ve gıda güvenliğini bir kenara bırakarak sadece verim odaklı yapılan tarım sistemlerinin asla sürdürülebilir bir tarafı kalmamıştır. Toprak, hava ve su kirlenmiş bu kirliliğin insan sağlığı ve çevreye verdiği zararların minimize edilmesi için ülkelerin ayırdığı bütçeler trilyon dolarlarla ifade edilmektedir.

Gelişmiş ülkelerde gıda güvenliği öncelikli konular haline gelmiş ve tarımsal üretimde kullanılan kimyasallara alternatif çözümler üzerine yoğun çabalar gösterilmektedir. Bu alternatif yöntemler içerisinde gerek bitki besleme gerekse de bitki koruma açısından biyolojik ve organik çözümler öncelikli konular haline gelmiştir. Bu alternatifler arasında biyolojik mücadele, mikrobiyal gübre, organik gübre, solucan gübresi ve yerel tohum konusunda toplumda ciddi bir farkındalık oluşmuştur. Tarımda kullanılan kimyasalların asla alternatifsiz olmadıkları yapılan bitki koruma ve bitki besleme ile ilgili çalışmalarda görülmektedir.

İnsanları açlık ile korkutarak, verim düşüklüğü ile tehdit ederek yıllardır yürütülen yanlışlıkların içerisinde tutma çabaları, dün olduğu gibi bugün de yarın da devam edecektir. Ancak bunun böyle olmadığı, yoğun tarım yapılan alanlarda bile ilk tedbir olarak kimyasallarda ciddi bir azaltmaya gitmek suretiyle devreye biyolojik ve organik çözümleri sokarak yıllar içerisinde topraklarımızda verim düşüklüğü yaşanan yerlerde sürdürülebilir bir üretim yapmanın hiç de zor olmadığı görülecektir. Toprağın canlı bir sistem olduğu ve bu canlı sistem içerisinde mikroorganizmaların muhteşem görevleri olduğu asla unutulmamalıdır. Bitkisel üretimde koruyucu önlemlerin çok önemli olduğu ve kültürel önlemler asla göz ardı edilmemelidir. Bitki besleme ve bitki korumanın birbirleri ile çok fazla ilişki olduğu bilinmelidir. Toprak, su ve hava ne kadar 
sağlıklı ise yetiştirdiğimiz bitkiler de o kadar sağlıklı ve olumsuz koşullara o kadar dayanıklı olacaktır.

Sonuç olarak; tarımda kullanılan biyolojik kökenli ürünler içerisinde mikroorganizma kullanımı, gerek bitki koruma gerekse de bitki besleme açısından her geçen gün önemi çok daha iyi anlaşılan bir konudur. Bakterilerin ve fungusların mikrobiyal gübre veya biyopestisit olarak tarımda kullanımına yönelik örnekleri artarak devam etmektedir. Dünyada ticari ürüne dönüşen pek çok mikrobiyal gübre ve biyopestisit bulunmaktadır. Ülkemizde de bu yöndeki çabalar azımsanmayacak kadar büyüktür. Özellikle son yıllarda yerli mikroorganizmalardan geliştirilen çok sayıda mikrobiyal gübre tescillendirilerek tarımda kullanıma sunulmuştur. Biyolojik mücadele konusunda da çok başarılı çalışmalar yapılmış ve bu konuda çalışan araştırıcıların mikroorganizma kültür koleksiyonlarında çok etkili biyopestisit olabilecek bakteri yada fungus kültürlerinin muhafaza edildiği bilinmektedir. Kotan (2020) uzun yıllardır yürütmüş olduğu çalışmalarında 13 farklı bitki zararlısı, 9 farklı bitki fungal hastalığı ve 8 farklı bitki bakteri hastalığı patojenine karşı \% 70 ile \%100 arasında değişen etkinliğe sahip çok sayıda yerli bakteri ya da fungal izolatın elde edildiğini ve bu kültürlerin gen bankasına girilerek muhafaza altına alındığını belirtmişdir. Ülkemizde bitki koruma ürünü ruhsatlandırılma aşamasında bazı konularda tıkanmalar görülmüş olsa da ileride bu konuların da çözüleceği ümidi taşınmaktadır. Entomopatojen fungusların ve mikorizaların tarımda kimyasallara karşı gerek bitki koruma gerekse de bitki beslemede başarılı bir şekilde kullanılabileceği özellikle vurgulanmak istenmektedir. Bu konuda yapılan çalışmaların biraz daha ileriye götürülmesi noktasında, taşıyıcı formülasyon çalışmalarına ağırlık verilmesi ve yönetmeliklerin bilimsel çalışmalara göre güncellenmesi ülkemiz tarımı açısından çok faydalı olacaktır.

\section{Çıkar Çatışması Beyanı}

Yazarlar, çıkar çatışması olmadığını beyan ederler.

\section{Araştırma ve Yayın Etiği Beyanı}

Yapılan çalışmada, araştırma ve yayın etiğine uyulmuştur.

\section{Kaynaklar}

Agrios, G. N. (2005). Plant pathology. Academic Press.

Alamy, (2012). https://www.alamy.com/stock-photo-development-of-entomopathogenic-fungus-verticilliumlecanii-on-aphid-49319046.html (Erişim tarihi: 19.01.2021)

Al-Karaki, G. N. (2000). Growth of mycorrhizal tomato and mineral acquisition under salt stress. Mycorrhiza, 10: 51-54. 
Ali S., Huang Z., ve Ren S. (2013). Effect of fungicides on growth, germination and cuticle-degrading enzyme production by Lecanicillium muscarium. Biocontrol Science and Technology, 23: 711-723.

Amutha, M., Gulsar Banu, J., Surulivelu, T., ve Gopalakrishnan, N. (2010). Effect of commonly used insecticides on the growth of white Muscardine fungus, Beauveria bassiana under laboratory conditions. Journal of Biopesticides, 3:143-146.

Anonim, (2015). Bitki Koruma Ürünleri ve Pestisit Kalıntıları. TC. Gıda Tarım ve Hayvancılık Bakanlığı Tarımsal Araştırmalar ve Politikalar Genel Müdürlüğü, Ezgi Ofset, ISBN: 978-605-9175-16-6.

Asi, M. R., Bashir, M. H., Afzal, M. vd. (2010). Compatibility of entomopathogenic fungi, Metarhizium anisopliae and Paecilomyces fumosoroseus with selective insecticides. Pakistan Journal of Botany, 42: 4207-4214.

Audoin, V. (1837). Nouvelles expériences sur la nature de la maladie contagieuse qui attaque les vers à soie et qu'on désigne sous le nom de Muscardine. Ann. Sci. Nat., 8, 257-270.

Ayyıldız, N., Emekci, M., ve Ferizli, A. G. (2018). Türkiye'de pestisitlerin ruhsatlandırılmasının tarihsel değişimi ve gelişimi üzerine değerlendirmeler. Türkiye Entomoloji Bülteni, 8(1-2): 35-50.

Avery, P. B., Pick, D. A., Aristizábal, L. F., vd. (2013). Compatibility of Isaria fumosorosea (Hypocreales: Cordycipitaceae) blastospores with agricultural chemicals used for management of the Asian citrus psyllid, Diaphorina citri (Hemiptera: Liviidae). Insects, 4: 694-711.

Bagga, S., Hu, G., Screen, S. E, ve Leger, R. J. S. (2004). Reconstructing the diversification of subtilisins in the pathogenic fungus Metarhizium anisopliae. Gene, 324: 159-169.

Barra-Bucarei, L., Iglesias, A. F., ve Torres, C. P. (2019). Entomopathogenic Fungi. In Natural Enemies of Insect Pests in Neotropical Agroecosystems (pp. 123-136). Springer, Cham.

Boruta, T. (2018). Uncovering the repertoire of fungal secondary metabolites: From Fleming's laboratory to the International Space Station. Bioengineered, 9 (1): 12-16.

Brakhage, A. A. (2013). Regulation of fungal secondary metabolism. Nature Reviews Microbiology, 11 (1): 21-32.

Butt, T. M., Jackson, C., ve Magan, N. (2001). Fungi as Biocontrol Agents, Progress, Problems and Potential, CABI Publishing, CAB International.

Cantürk, Z. (2015). Aspergillus ve Penicillium cinslerine ait sekonder metabolitler ve sinıflandırılması. Elektronik Mikrobiyoloji Dergisi TR, 13 (2): 1-8.

Castro, T., Mayerhofer, J., Enkerli, J., Eilenberg, J., Meyling, N. V., de Andrade Moral, R., ... ve Delalibera Jr, I. (2016). Persistence of Brazilian isolates of the entomopathogenic fungi Metarhizium anisopliae and $M$. robertsii in strawberry crop soil after soil drench application. Agriculture, Ecosystems \& Environment, 233, 361-369.

Ceballos, I., Ruiz, M., Fernandez, C., Pena, R., Rodriguez, A., ve Sanders, I. R. (2013). The in vitro mass produced model mycorrhizal fungus, Rhizophagus irregularis, significantly increases yields of the globally important food security crop Cassava. PLoS ONE, 8: e70633.

Celar, F. A, ve Kos, K. (2016). Effects of selected herbicides and fungicides on growth, sporulation and conidial germination of entomopathogenic fungus Beauveria bassiana. Pest Management Science, 72:2110-2117.

Dağ, S. (2000). Türkiye'de Tarım İlaçları Endüstrisi ve Geleceği, V. Türkiye Ziraat Mühendisliği Teknik Kongresi Bildirileri 2. Cilt, TMMOB Ziraat Mühendisleri Odas1, Ankara, s. 933-958, 17-21 Ocak 2000. 5 .

D’Alessandro, C. P., Padin, S., Urrutia, M. I., ve López Lastra, C. C. (2011). Interaction of fungicides with the entomopathogenic fungus Isaria fumosorosea. Biocontrol Science and Technology, 21: 189197.

Dara, S. K. (2017). Entomopathogenic microorganisms: modes of action and role in IPM. Agriculture and Natural Blogs, University of California, 7p.

Davis, J. R., Brownson, R. C., Garcia, R., Bentz, B. J., ve Turner, A. (1993). Family pesticide use and childhood brain cancer. Archives of Environmental Contamination and Toxicology, 24 (1): 87-92.

Dehne, H. W., ve Schanbeck, F. (1979). Untersuchungen zum Einfluss der Endotrophen Mykorrhiza auf Pflanzenkrankheiten. II. Phenolstoffwechsel und Lignifizierung, Phytopathology, 95, 214-216. 
Avan, M., Kotan, R., Uluslararası Doğu Anadolu Fen Mühendislik ve Tasarım Dergisi / International Journal of Eastern Anatolia Science Engineering and Design (IJEASED)

(2021) 3(1):167-191

Delen N., Durmuşoğlu E., Güncan A., Güngör N., Turgut C., ve Burçak A. (2005). Türkiye'de Pestisit Kullanımı, Kalıntı ve Organizmalarda Duyarlılık Azalışı Sorunları, VI. Türkiye Ziraat Mühendisliği Teknik Kongresi.

Delen, N., Tiryaki, O., Türkseven, S., ve Temur, C. (2015). Türkiye'de pestisit kullanımı kalıntı ve dayanıklılık sorunları, çözüm önerileri ss, 758-778. Türkiye Ziraat Müh. VIII. Teknik Kongresi, 12-16 Ocak 2015, Türkiye.

Demirci, F., Muştu, M., Kaydan, M. B., ve Ülgentürk, S. (2011). Effects of some fungicides on Isariafarinosa, and in vitro growth and infection rate on Planococcus citri. Phytoparasitica, 39: 353360.

Doğan, Z., Arslan, S., ve Berkman, A. N. (2015). Türkiye'de Tarım Sektörünün İktisadi Gelişimi ve Sorunları. Niğde Üniversitesi İktisadi ve İdari Bilimler Fakültesi Dergisi, 8 (1): 29-41. ISSN: 2148 5801.

E-Journal of Entomology and Biologicals (2017).

https://ucanr.edu/blogs/blogcore/postdetail.cfm?postnum=24119. (Erişim tarihi: 19.01.2021)

Fiedler, Z., ve Sosnowska, D. (2017). Side effects of fungicides and insecticides on entomopathogenic fungi in vitro. Journal of Plant Protection Research, 57: 355-360.

Forestry images, (2018). https://www.forestryimages.org/browse/detail.cfm?imgnum=5368217. (Erişim tarihi: 19.01.2021)

Forlani, L., Juárez, M. P., Lavarías, S., ve Pedrini, N. (2014). Toxicological and biochemical response of the entomopathogenic fungus Beauveria bassiana after exposure to deltamethrin. Pest Management Science, 70: 751-756.

Gelernter, W. D., ve Lomer, C. J. (2000). Success in biological control of above-ground insects by pathogens. In: Gurr G, Wratten S (eds) Biological control: measures of success. Kluwer Academic, Dordrecht, The Netherlands, pp 297-322.

Ghorbanpour, M., Omidvari, M., Abbaszadeh-Dahaji, P., Omidvar, R., ve Kariman, K. (2017). Mechanisms underlying the protective effects of beneficial fungi against plant diseases. Biological Control, 117: 147-157.

Goettel, M. S., ve Hajek, A. E. (2000). Evaluation of non-target effects of pathogens used for management of arthropods. In: Wajnberg E, Scott JK, Quimby PC (eds) Evaluating indirect ecological effects of biological control. CABI Publishing, Wallingford, pp 81-97.

Gola, D., Malik, A., Namburath, M., ve Ahammad, S. Z. (2018). Removal of industrial dyes and heavy metals by Beauveria bassiana: FTIR, SEM, TEM and AFM investigations with $\mathrm{Pb}(\mathrm{II})$.Environmental Science and Pollution Research, 25: 20486-20496.

Government of Canada, (2013). Arbuscular Mycorrhizal Fungi and their Symbiosis with Plants. Erişim adresi: https://www.agr.gc.ca/eng/scientific-collaboration-and-research-in-agriculture/agriculture-andagri-food-research-centres-and-collections/glomeromycota-in-vitro-collection-ginco/arbuscularmycorrhizal-fungi-and-their-symbiosis-with-plants/?id=1236712919454.

Harley, J. L., Smith, S. E. (1983) Mycorrhizal symbiosis. Academic Press, New York.

Hirose, E., Neves, P. M. O. J., Zequi, J. A. C. vd. (2001). Effect of biofertilizers and neem oil on the entomopathogenic fungi Beauveria bassiana (bals.) vuill. and Metarhizium anisopliae (Metsch.) sorok. Brazilian Archives of Biology and Technology, 44: 419-423.

Huang, W. L., He, Y. F., Xiao, J. F., Huang, Y. N., Li, A., He, M. R., ve Wu, K. S. (2019). Risk of breast cancer and adipose tissue concentrations of polychlorinated biphenyls and organochlorine pesticides: a hospital-based case-control study in Chinese women. Environmental Science and Pollution Research, 26 (31): 32128-32136.

Ijdo, M., Cranenbrouck, S., ve Declerck, S. (2011). Methods for large-scale production of AM fungi: past, present, and future. Mycorrhiza, 21: 1-16.

Isaac, S. (1992). Fungal Plant Interactions. Chapman and Hall, London, UK, p.418.

Jaihan, P., Sangdee, K., ve Sangdee, A. (2016). Selection of entomopathogenic fungus for biological control of chili anthracnose disease caused by Colletotrichum spp. European Journal of Plant Pathology, 146: $551-564$. 
Jungle Dragon, (2019).

https://www.jungledragon.com/image/69157/dead razor grinder cicada with a fungus growing on it.htm 1. (Erişim tarihi: 19.01.2021)

Kafaei, R., Arfaeinia, H., Savari, A., Mahmoodi, M., Rezaei, M., Rayani, M., Sorial, G.A., Fattahi, N., ve Ramavandi, B. (2019). Organochlorine pesticides contamination in agricultural soils of southern Iran. Chemosphere, 240, DOI: 10.1016/j.chemosphere.2019.124983.

Khan, S., Guo, L., Maimaiti, Y., vd. (2012). Entomopathogenic fungi as microbial biocontrol agent. Molecular Plant Breeding, 3(7).

Kotan, R. (2020). Tarımda Biyolojik Çözümler. Harman Yayıncılık, İstanbul, ISBN: 978-605-68060-4-9. Haziran 2020. Sayfa: 158

Kouassi, M., Coderre, D., ve Todorova, S. I. (2003). Effects of the timing of applications on the incompatibility of three fungicides and one isolate of the entomopathogenic fungus Beauveria bassiana (Balsamo) Vuillemin (Deuteromycotina). Journal of Applied Entomology, 127: 421-426.

Krassilstschik, J. (1888). La production industrielle des parasites ve'ge'taux pour la destruction des insectes nuisibles. Bulletin Biologique de la France et de la Belgique 19: 461-472.

Labroots, (2017). https://www.labroots.com/trending/microbiology/5707/insects-beware-fungi-meanbusiness. (Erişim tarihi: 19.01.2021).

LeConte, J. L. (1874). Hints for the promotion of economic entomology. Proceedings of the American Association for the Advancement of Science, 22, 10-22.

Litwin, A., Nowak, M., ve Różalska, S. (2020). Entomopathogenic fungi: unconventional applications. Reviews in Environmental Science and Bio/Technology, 1-20.

Lovett, B., ve Leger, R. J. S. (2017). The insect pathogens. Microbiology Spectrum, 5: 1-19.

Maina, U. M., Galadima, I. B., Gambo, F. M., ve Zakaria, D. (2018). A review on the use of entomopathogenic fungi in the management of insect pests of field crops. Journal of Entomology and Zoology Studies, 6 (1), 27-32.

Malik, R. J., Dixon, M. H., ve Bever, J. D. (2016). Mycorrhizal composition can predict foliar pathogen colonization in soybean. Biological control, 103: 46-53.

Marschner, H., ve Dell, B. (1994). Nutrient uptake in mycorrhizal symbiosis. Plant Soil, 159: 89-102.

Millner, P. D. (1991). Charectarization and use of Vesicular Arbuscular Mycorrhizae in Agricultural Production Systems. The Rizosphere and Plant Growth (Editors: Keister, D.L. and Cregan P.B.). Kluwer Academic Publishers, Netherlands, 335-342.

Mohan, V., Nivea, R., ve Menon, S. (2015). Evaluation of ectomycorrhizal fungi as potential bio-control agents against selected plant pathogenic fungi, Journal of Artificial Intelligence Research, 3: 408-412.

Moore, D., Douro-Kpindou, O. K., Jenkins, N. E., ve Lomer, C. J. (1996). Effects of moisture content and temperature on storage of Metarhizium flavoviride conidia. Biocontrol Science and Technology, 6, 5162.

Nair, A., Kolet, S. P., Thulasiram, H. V., ve Bhargava, S. (2014). Systemic jasmonic acid modulation in mycorrhizal tomato plants and its role in induced resistance against Alternaria alternata. Plant Biology, 17 (3): 625-663.

Nassimi, Z., ve Taheri, P. (2017). Endophytic fungus Piriformospora indica induced systemic resistance against rice sheath blight via affecting hydrogen peroxide and antioxidants. Biocontrol Science and Technology, 27: 1-16.

Neves, P. M. O. J., Hirose, E., Tchujo, P. T., ve Moino, A. (2001). Compatibility of entomopathogenic fungi with neonicotinoid insecticides. Neotropical Entomology, 30: 263-268.

Ortaş, İ. (1997). Mikoriza nedir? TÜBİTAK Dergisi Şubat 1997 sayı: 351 Ankara.

Pasteur, L. (1874). Observations (au sujet des conclusions de M. Dumas) relatives au phylloxera C. R. Hebd. Seances Acad. Sci., 79, 1233-1234.

Pell, J. K., Eilenberg, J., Hajek, A. E., ve Steinkraus, D. C. (2001). Biology, ecology and pest management potential of Entomophthorales. In: Butt TM, Jackson C, Magan N (eds) Fungi as biocontrol agents: progress, problems and potential. CAB International, Wallingford, pp 71-153.

Peterson, R. L., Massicotte, H. B., ve Melville, L. H. (2004). Mycorrhizas: anatomy and cell biology. Ottawa, ON, Canada: NRC Research Press. 
Avan, M., Kotan, R., Uluslararası Doğu Anadolu Fen Mühendislik ve Tasarım Dergisi / International Journal of Eastern Anatolia Science Engineering and Design (IJEASED)

(2021) 3(1):167-191

Pfeiffer, C. M., ve Bloss, H. E. (1988). Growth and nutrition of guayule (Parthenium argentatum) in saline soil as influenced by vesicular-arbuscular mycorrhiza and phosphorus fertilization. New Phytologist, 108, 315-321.

Read, D. J., ve Perez-Moreno, J. (2003). Mycorrhizas and nutrient cycling in ecosystems - a journey towards relevance? New Phytologist, 157: 475-492.

Reddy, D. S., Reddy, M., ve Pushpalatha, M. (2018). Interaction of fungicides with bio-control agents. Journal of Entomology and Zoology, 3: 2098-2104.

Ríos-Moreno, A., Garrido-Jurado, I., Resquín-Romero, G., vd. (2016). Destruxin A production by Metarhizium brunneum strains during transient endophytic colonisation of Solanum tuberosum. Biocontrol Science and Technology, 26: 1574-1585.

Ruiz Lazano, J. M. (2003). Antioxidant activities in mycorrhizal soybean plants under drought stress. New Phytologist, 157(1): 135-143.

Schouteden, N., De Waele, D., Panis, B., ve Vos, C. M. (2015). Arbuscular mycorrhizal fungi for the biocontrol of plant-parasitic nematodes: a review of the mechanisms involved. Frontiers in Microbiology, 6: 1280.

Shah, F. A, Ansari, M. A., Watkins, J., vd. (2009). Influence of commercial fungicides on the germination, growth and virulence of four species of entomopathogenic fungi. Biocontrol Science and Technology, 19: 743-753.

Shim, Y. K., Mlynarek, S. P., ve van Wijngaarden, E. (2009). Parental Exposure to Pesticides and Childhood brain cancer: US Atlantic Coast Childhood Brain Cancer Study. Environmental Health Perspectives, 117 (6): 1002-1006.

Sivakumar, T, Jiji, T., ve Naseema, A. (2019). Effect of pesticides used in banana agro-system on entomopathogenic fungus, Metarhizium majus Bisch, Rehner and Humber. International Journal of Tropical Insect Science, 1-9.

Smith, S. E., ve Read, D. J. (1996). Mycorrhizal symbiosis, Academic press, p. 1-611.

Smith, S. E., ve Read D. J. (2008). Mycorrhizal symbiosis (3rd edn). Elsevier-Academic Press, London,UK, pp. 787.

Subbanna, A. R. N. S., Stanley, J., Venkateswarlu. V., vd. (2019). Toxicological prospects on joint action of microbial insecticides and chemical pesticides. In: Khan MA, Ahmad W (eds) Microbes for sustainable insect pest management. Springer, Cham, pp 317-340.

Szewczyk, R., Kuśmierska, A., ve Bernat, P. (2018). Ametryn removal by Metarhizium brunneum: biodegradation pathway proposal and metabolic background revealed. Chemosphere, 190: 174-183.

Tahat, M., Kamaruzaman, S., ve Othman, R. (2010). Mycorrhizal fungi as a biocontrol agent. Plant Pathology Journal, 9: 198-207.

The Ground up (2018). Mycorrhizal Fungi. Erişim adresi:

https://thegroundup.com/blog/tag/Mycorrhizal+Fungi. (Erişim tarihi: 19.01.2021)

Tiryaki, O., Canhilal, R., ve Horuz, S. (2010). Tarım ilaçları kullanımı ve riskleri. Erciyes Üniversitesi Fen Bilimleri Enstitüsü Dergisi, 26 (2): 154-169.

Tiryaki, O. (2016). Türkiye'de yapılan pestisit kalıntı analiz ve çalışmalar. Erciyes Üniversitesi Fen Bilimleri Enstitüsü Dergisi, 32 (1): 72-82.

Tkaczuk, C., Harasimiuk, M., Król, A., ve Beres, P. K. (2015). The effect of selected pesticides on the growth of entomopathogenic fungi Hirsutella nodulosa and Beauveria bassiana. Journal of Ecological Engineering, 16: 177-183.

Todorova, S. I., Coderre, D., Duchesne, R. M., ve Côté, J. C. (1998). Compatibility of Beauveria bassiana with selected fungicides and herbicides. Environmental Entomology, 27: 427-433.

Tozlu, E., Kotan, R. ve Tozlu, G. (2017). The investigation of Beauveria bassiana (Ascomycota: Hypocreales) as a biocontrol agent of rose-stem sawfly, Syrista parreyssii (Spinola, 1843) (Hymenoptera: Symphyta; Cephidae) larvae. Fresenius Environmental Bulletin, 26 (12): 7091-7100.

Tozlu, E., Tekiner, N., Tozlu, G., Kotan, R., Çalmaşur, Ö., Göktürk, T. , et al. (2018a). Icerya purchasi Maskell, 1878 (Hemiptera: Margarodidae)'nin Entomopatojen Fungus ve Bakterilerle Biyolojik Mücadelesinin Araştırılması. Türkiye III. Orman Entomolojisi ve Patolojisi Sempozyumu, Artvin, Türkiye, 10-12 Mayıs 2018, ss.43-43. 
Tozlu, E., Tekiner, N. ve Kotan R. (2018b). Screening of Trichoderma harzianum Rifai (1969) isolates of domestic plant origin against different fungal plant pathogens for use as biopesticide. Fresenius Environmental Bulletin, 27 (6): 4232-4238.

Tuli, H. S., Sandhu, S. S. ve Sharma, A. K. (2014). Pharmacological and therapeutic potential of Cordyceps with special reference to Cordycepin. 3 Biotech, 4, 1-12.

TÜiK, (2019). Türkiye'de Pestisit Kullanım Miktarları. http://www.tuik.gov.tr (Erişim tarihi: 17.04.2019).

Uygun, N. (2002). Zararlılara karşı biyolojik mücadelede gelişmeler, s. 23-31. Türkiye 5. Biyolojik Mücadele Kongresi, Eylül 4-7, 2002, Erzurum.

Valero-Jiménez, C. A., Wiegers, H., Zwaan, B. J., Koenraadt, C. J. M., ve van Kanc., J. A. L. (2016). Genes involved in virulence of the entomopathogenic fungus Beauveria bassiana. Journal of Invertebrate Pathology, 133: 41-49.

van der Heijden, M.G., Martin, F.M., Selosse, M.A., ve Sanders, I.R. (2015). Mycorrhizal ecology and evolution: the past, the present, and the future. New phytologist, 205 (4), 1406-1423.

Vega, F. E., Goettel, M. S., Blackwell, M., Chandler, D., Jackson, M. A., Keller, S., ... ve Roy, H. E. (2009). Fungal entomopathogens: new insights on their ecology. Fungal ecology, 2(4), 149-159.

Vos, C. M., Yang, Y., De Coninck, B., ve Cammue, B. P. A. (2014). Fungal (-like) biocontrol organisms in tomato disease control. Biological control, 74: 65-81.

Vosátka, M., Látr, A., Gianinazzi, S., ve Albrechtová, J. (2012). Development of arbuscular mycorrhizal biotechnology and industry: current achievements and bottlenecks. Symbiosis, 58: 29-37.

Wikipedia, (2021a). https://en.wikipedia.org/wiki/Entomopathogenic_fungus. (Erişim tarihi: 19.01.2021)

Wikipedia, (2021b). https://en.wikipedia.org/wiki/Metarhizium_anisopliae. (Erişim tarihi: 19.01.2021)

Wu, S., Kostromytska, O. S., Goble, T., vd. (2020). Compatibility of a microsclerotial granular formulation of the entomopathogenic fungus Metarhizium brunneum with fungicides. Biocontrol, 9: 113-123.

Xiao, G., Ying, S. H., Zheng, P., Wang, Z. L., Zhang, S., Xie, X. Q., Shang, Y., St Leger, R. J., Zhao, G. P., Wang, C., vd. (2012). Genomic perspectives on the evolution of fungal entomopathogenicity in Beauveria bassiana. Scientific Reports, 2, 483.

Zheng, P., Xia, Y. L., Xiao, G. H., Xiong, C. H., Hu, X., Zhang, S. W., Zheng, H. J., Huang, Y., Zhou, Y., Wang, S. Y., vd. (2011). Genome sequence of the insect pathogenic fungus Cordyceps militaris, a valued traditional chinese medicine. Genome Biology, 12. 